\title{
Influenza prevention and treatment by passive immunization
}

\author{
Barbara Kalenik\#, Róża Sawicka\#, Anna Góra-Sochacka and Agnieszka Sirko ${ }^{\bowtie}$ \\ Institute of Biochemistry and Biophysics, Polish Academy of Sciences, Warsaw, Poland
}

\begin{abstract}
Passive immunity is defined as a particular antigen resistance provided by external antibodies. It can be either naturally or artificially acquired. Natural passive immunization occurs during pregnancy and breast-feeding in mammals and during hatching in birds. Maternal antibodies are passed through the placenta and milk in mammals and through the egg yolk in birds. Artificial passive immunity is acquired by injection of either serum from immunized (or infected) individuals or antibody preparations. Many independent research groups worked on selection, verification and detailed characterization of polyclonal and monoclonal antibodies against the influenza virus. Numerous antibody preparations were tested in a variety of in vitro and in vivo experiments for their efficacy to neutralize the virus. Here, we describe types of antibodies tested in such experiments and their viral targets, review approaches resulting in identification of broadly neutralizing antibodies and discuss methods used to demonstrate their protective effects. Finally, we shortly discuss the phenomenon of maternal antibody transfer as a way of effective care for young individuals and as an interfering factor in early vaccination.
\end{abstract}

Key words: antibody, clinical trials, hemagglutinin, influenza, neutralization, passive immunity

Received: 18 July, 2014; revised: 01 September, 2014; accepted: 01 September, 2014; available on-line: 12 September, 2014

\section{INTRODUCTION}

Antibodies (Abs) are glycoproteins produced by activated $B$ cells. They are able to bind toxic and antigenic proteins of pathogens. Some Abs can directly neutralize pathogens and/or they can evoke a potent antibodydependent cell-mediated cytotoxicity (ADCC) and complement dependent cytotoxicity (CDC). Neutralizing Abs defend organisms (or cells when tested in vitro) against pathogens by blocking essential functions of their target antigens. The term "broadly neutralizing Ab" means that such an $\mathrm{Ab}$ can recognize and neutralize multiple variants of highly variable antigens, which is particularly important in protection against fast mutating viruses, such as the influenza virus.

Artificial passive immunization relies on administration of pathogen-specific and neutralizing Abs present in the serum of an immunized individual or purified either from such a serum or from any protein expression system. This process leads to curing of the existing infection (therapeutic immunization) and/or to a short-term protection against subsequent infections (protective immunization). The first successful case of artificial passive immunization was recorded for diphtheria therapy in the late 19th century (see: (Schirrmann et al., 2011; Virdi \& Depicker, 2013) and references within). Since that time, passive therapy has been used under many conditions, including prevention of tetanus, auto inflammatory disorders and neutralization of snake toxins (Keller \& Stiehm, 2000). Increasing knowledge led to huge technological improvement in Ab-based therapy. Direct serum transfusions or Ab filtrates have been replaced by monoclonal antibodies (mAbs), pre-selected in high-throughput screening procedures and carefully characterized by modern techniques (Brekke \& Loset, 2003). Passive immunization does not cause long-term protection because of the relatively short $\mathrm{Ab}$ half-life. Yet, externally produced Abs can be a source of a quick, specific help to an organism in danger. Accordingly, passive immunization seems to be useful rather in special cases, such as protection of newborns, elderly or immune-compromised patients, than in preventive and broadly conducted treatments.

Reports on successful application of passive immunization include anti-fungal therapy (Bugli et al., 2013) and treatment of neurodegenerative syndromes such as Alzheimer's disease, Parkinson's disease, Huntington's disease or amyotrophic lateral sclerosis (Huang et al., 2013). Furthermore, drugs based on mAbs, such as Infliximab for rheumatoid arthritis and Crohn's disease, Palivizum$\mathrm{ab}$ for respiratory syncytial virus, Gemtuzumab for relapsed acute myeloid leukemia, have been approved for clinical application and additional ones are being evaluated in clinical trials (Brekke \& Loset, 2003). Recently, the concept of application of Abs as therapeutic or prophylactic agents in infectious diseases caused by pathogens such as human immunodeficiency virus or herpes simplex virus was reviewed and the efficacy of topical or systemic delivery of such antibodies discussed (Whaley \& Zeitlin, 2013).

e-mail: asirko@ibb.waw.pl

\#these authors contributed equally to this work

Abbreviations: aa, amino acids; Ab, antibody; ADCC, antibody-dependent cell-mediated cytotoxicity; CDC, complement dependent cytotoxicity; CDR, complementarity determining regions; dpi, days post infection; EBVi, Epstein-Barr Virus immortalized; Fab, antibody fragment containing $\mathrm{VH}+\mathrm{CH} 1$ and $\mathrm{VL}+\mathrm{CL} 1 ; \mathrm{F}\left(\mathrm{ab} \mathrm{b}^{\prime}\right) 2, \mathrm{Ab}$ fragment containing two Fab fragments connected by a hinge; Fc, fragment crystallizable region; FR, framework regions; Fv, variable fragment of immunoglobulin; $\mathrm{H} 1-\mathrm{H} 18$, types of $\mathrm{HA}$; $\mathrm{HA}$, hemagglutinin; hclgG, heavy chain-only antibody from camelides; HI, Hemagglutination Inhibition; H-IVIG, hyperimmune intravenous immunoglobulin; IgG, mammalian immunoglobulin (one of isotypes); IgY, chicken yolk immunoglobulins; mAb, monoclonal antibody; NA, neuraminidase; NIAID, U.S. National Institute of Allergy and Infectious Diseases; $\mathrm{pAb}$, polyclonal antibody; PBMC, peripheral blood mononuclear cells; RBS, receptor binding site; scFv single-chain Fv; $\mathrm{VL}$, variable domain of light chain; $\mathrm{VH}$, variable domain of heavy chain; $\mathrm{VHH}$, single-domain variable fragment. 
Influenza viruses are constantly evolving in order to escape neutralizing Abs raised by previous infections or vaccinations. Accumulation of amino acid mutations in major surface glycoproteins of the influenza virus (antigenic drift) results in a failure of pre-existing Abs to efficiently recognize those newer, drifted variants. Therefore, identification of Abs able to target the conserved neutralizing epitopes broadly shared among different influenza variants is important if we want to overcome the necessity of regular (seasonal) updates of anti-influenza vaccine composition and the ensuing problems. Studies on passive immunization against influenza viruses gave hope for creation of the pools of properly described broadly neutralizing Abs, ready for every possible change of the antigenic properties of the major influenza antigens. Multiple examples of such Abs and their experimental application in prophylactic and therapeutic treatment of influenza can be found in recent reviews (Clementi et al., 2012; Laursen \& Wilson, 2013). In this review we focus on interesting approaches used for identification of neutralizing Abs and on major techniques applied to demonstrate their effectiveness in the virus neutralization. We also discuss the role of natural maternal immunity in passive immunization against influenza.

\section{TYPES OF ANTIBODIES AND RECOMBINANT ANTIBODY FRAGMENTS USED FOR EXPERIMENTAL TREATMENT OF INFLUENZA VIRUS}

For many years passive immunization relied on sera containing $\mathrm{Ab}$ mixtures, however development of molecular techniques allowed for creation of mAbs, which can be precisely characterized and produced under sterile conditions. Different variants of mAbs used in influenza virus challenge experiments demon- strated protective and therapeutic effects. They include full-length and fragments of conventional mammalian immunoglobulins consisting of heavy and light chains ( $\mathrm{IgG})$, chicken yolk immunoglobulins (IgY) and heavy chain-only antibodies from camelides (hcIgG). Schematic structures of these variants are shown in Fig. 1. The full-length Ab consists of constant and variable domains. Each variable fragment (Fv) contains an antigen-interaction site, the only part of the $\mathrm{Ab}$ determining its antigenic specificity. It is formed by variable fragments of the heavy and light chain $(\mathrm{VH}$ and VL, respectively), each built from four framework regions (FR) and three complementarity determining regions (CDR). The $\mathrm{Fv}_{\mathrm{V}}$ fragment of conventional IgG or $\mathrm{IgY}$ functions only when the variable domains are connected by a disulfide bond (which occurs when at least one pair of the constant region such $\mathrm{C}_{\mathrm{H}} 1$ and $\mathrm{C}_{\mathrm{L}} 1$ is connected to $\mathrm{Fv}$ ) or connected via the linker sequence with a single-chain variable fragment $(\mathrm{scFv})$. Although scFv can be useful for research purposes, clinical application of such polypeptides is limited because of their reduced stability and shorter half-life in comparison to the full-length Abs. Moreover, soluble $\mathrm{scFv}_{\mathrm{v}}$ might have its specificity altered in comparison to a phage-bound $\mathrm{scFv}$ or a $\mathrm{scFv}$ converted to $\mathrm{mAb}$ (Kaku et al., 2012). The scFv fused to a protein transduction domain (or a cell-penetrating peptide) is called transbody. It can translocate across the cell membrane and can be easily internalized (Heng \& Cao, 2005) accessing virus proteins inside the infected cells and targeting internal viral proteins (Poungpair et al., 2010; Mukhtar et al., 2009). An Ab fragment where the VH and VL are connected with parts of constant fragments $\left(C_{H} 1\right.$ and $C_{L} 1$, respectively) is named Fab, while an $\mathrm{Ab}$ fragment obtained by cleavage of full-length $\mathrm{Ab}$ and containing two Fab fragments connected by a hinge forms an $\mathrm{F}(\mathrm{ab})_{2}$. Obtained from hcIgG single-

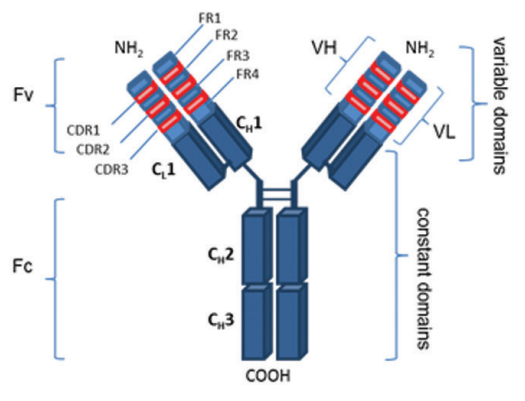

$\lg G$

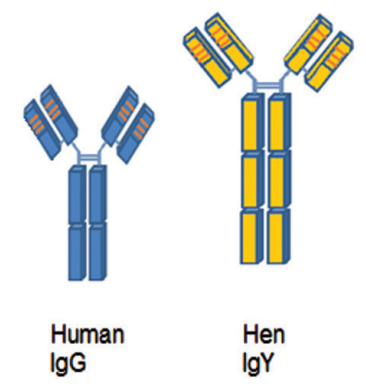

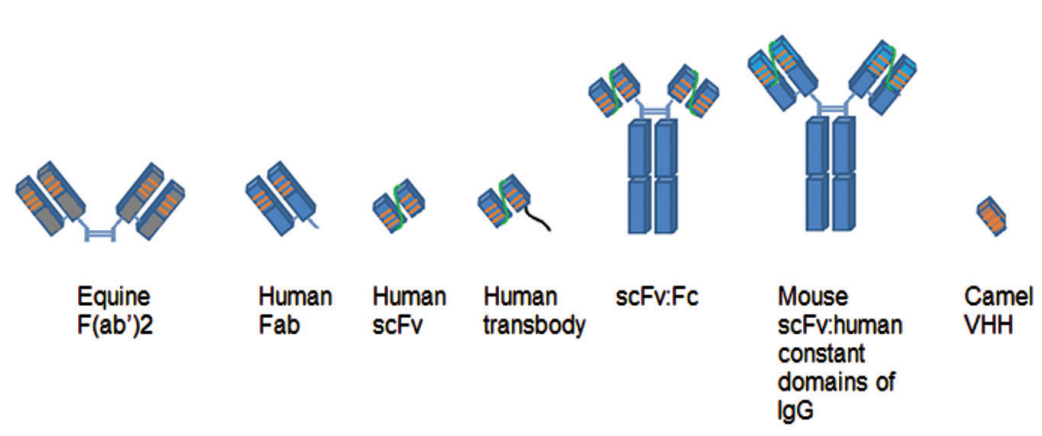

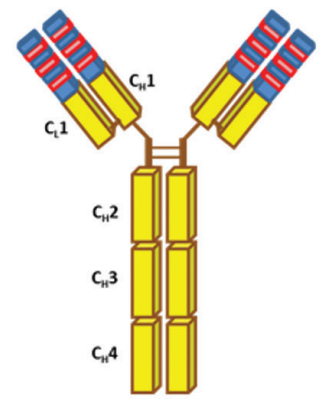

$\lg Y$

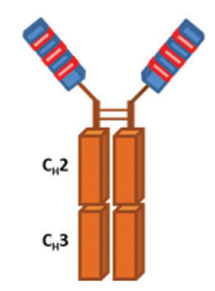

hclgG

Figure 1. Schematic structure of full-length conventional IgG, chicken IgY, heavy chain-only camelide IgG (hclgG) and their various recombinant fragments used in passive immunization experiments against influenza virus. Antibody fragments and domains were labeled only for IgG (see the text for explanation). 
domain variable fragments $(\mathrm{VHH}$, also called nanoantibody) are smaller and can penetrate tissues better than conventional Abs (Tillib et al., 2013). Moreover, they can recognize some hidden epitopes that are inaccessible to conventional antibodies. For some applications, especially in treatment of acute infections caused by variable pathogens such as highly pathogenic influenza viruses, polyclonal antibodies (pAbs) might give better results than mAbs. They can be either obtained from immunized subjects or formulated as a mixture of a few known mAbs (Prabakaran et al., 2009; Rinaldi et al., 2014; Simmons et al., 2007; Wallach et al., 2011).

Besides the strategy of passive immunization based on direct delivery of $\mathrm{Ab}$ variants, it is worth to mention several approaches based on delivery of the genetic material encoding $\mathrm{Ab}$ fragments to the recipient organism. Both, recombinant adenoviral vectors and appropriate plasmids were used as tools for such DNA-based passive immu- nization. Administration of such vaccines resulted in a production of expected antibodies in the recipient cells and in protection against a challenge with influenza virus (Balazs et al., 2013; Tutykhina et al., 2013; Yamazaki et al., 2011).

\section{ANTIBODIES SUITABLE FOR ANTI-INFLUENZA TREATMENT AND THEIR VIRAL TARGETS}

Viral neutralization is interpreted as the elimination of viral infectivity. The mechanism of action of neutralizing antibodies depends on their target site (RBS of HA1, fusion peptide etc.) and can rely on disturbing the virion binding to receptors, blocking virion uptake into the cells or precluding fusion of the viral envelope with the host endosome membrane. Neutralizing antibodies targeting various antigens of influenza virus have been described in earlier reviews, such as a review on monoclonal antibodies directed against vari-

Table 1. Examples of broadly neutralizing antibodies with anti-influenza virus activity confirmed in vivo.

\begin{tabular}{|c|c|c|c|c|c|c|c|}
\hline $\begin{array}{l}\text { Neutralized } \\
\text { group of } \\
\text { influenza } \\
\text { viruses }\end{array}$ & Name & Target of $\mathrm{Ab}$ & Form of $\mathrm{Ab}$ & Mechanism (if known) & $\begin{array}{l}\text { Organism, tissue, } \\
\text { isolation method }\end{array}$ & $\begin{array}{l}\text { Organisms } \\
\text { used to } \\
\text { confirm } \\
\text { protection }\end{array}$ & References \\
\hline $\begin{array}{l}\text { Influenza A } \\
\text { and B }\end{array}$ & CR9114 & $\mathrm{HA} 2$ & $\mathrm{mAb}$ & $\begin{array}{l}\text { blocks the } \mathrm{HA} \text { pH-indu- } \\
\text { ced conformational } \\
\text { changes associated } \\
\text { with membrane fusion }\end{array}$ & $\begin{array}{l}\text { Human, periphe- } \\
\text { ral B-cells, Phage } \\
\text { display }\end{array}$ & mice & $\begin{array}{l}\text { (Dreyfus et al., } \\
\text { 2012) }\end{array}$ \\
\hline \multirow{4}{*}{$\begin{array}{l}\text { Influenza A } \\
\text { group } 1 \text { and } \\
\text { group } 2\end{array}$} & PN-SIA28 & $\begin{array}{l}\text { Stem } \\
\text { (HA1 and HA2) }\end{array}$ & Fab & & $\begin{array}{l}\text { Human, } \\
\text { peripheral B-cells, } \\
\text { Human modified } \\
\text { hybridoma }\end{array}$ & not done & $\begin{array}{l}\text { (Clementi et } \\
\text { al., 2011) }\end{array}$ \\
\hline & Fl6, Fl6v3 & $\begin{array}{l}\text { fusion peptide } \\
\text { (HA2) }\end{array}$ & & $\begin{array}{l}\text { inhibits membrane } \\
\text { fusion and perhaps } \\
\text { HAO cleavage }\end{array}$ & $\begin{array}{l}\text { Human, periphe- } \\
\text { ral B-cells, }\end{array}$ & $\begin{array}{l}\text { ferrets, } \\
\text { mice }\end{array}$ & $\begin{array}{l}\text { (Corti et al., } \\
2011 \text { ) }\end{array}$ \\
\hline & S139/1 & $\begin{array}{l}\text { non-contigu- } \\
\text { ous conforma- } \\
\text { tional epitope } \\
\text { near RBS (HA1) }\end{array}$ & $\lg G 2 a$ & $\begin{array}{l}\text { inhibit binding to sia- } \\
\text { lyl-glycan receptors }\end{array}$ & $\begin{array}{l}\text { Mouse, splenocy- } \\
\text { tes, hybridoma }\end{array}$ & mice & $\begin{array}{l}\text { (Yoshida et al., } \\
\text { 2009); (Velkov } \\
\text { et al., 2013) }\end{array}$ \\
\hline & C05 & RBS (HA1) & $\mathrm{mAb}$ & & $\begin{array}{l}\text { Human, Bone } \\
\text { marrow, Phage } \\
\text { display }\end{array}$ & mice & $\begin{array}{l}\text { (Ekiert et al., } \\
\text { 2012) }\end{array}$ \\
\hline \multirow{4}{*}{$\begin{array}{l}\text { Influenza A } \\
\text { group } 1\end{array}$} & CR6261 & $\begin{array}{l}\text { Stem } \\
\text { (HA1 and HA2), }\end{array}$ & $\begin{array}{l}\text { scFv- } \\
\text {-phages, } \\
\text { full length } \\
\text { lgG1 }\end{array}$ & $\begin{array}{l}\text { stabilization of pre-fu- } \\
\text { sion state and inhibit } \\
\text { membrane fusion }\end{array}$ & $\begin{array}{l}\text { Human, } \\
\text { FACS sorted me- } \\
\text { mory B-cells, } \\
\text { Phage display }\end{array}$ & mice & $\begin{array}{l}\text { (Throsby et al., } \\
\text { 2008); (Velkov } \\
\text { et al., 2013) }\end{array}$ \\
\hline & $\begin{array}{l}\text { D8, F10, } \\
\text { A66 }\end{array}$ & $\mathrm{HA} 2$ & $\begin{array}{l}\text { scFv-Fcs*; } \\
\operatorname{lgG} 1^{* *}\end{array}$ & $\begin{array}{l}\text { inhibits membrane } \\
\text { fusion }\end{array}$ & $\begin{array}{l}\text { "Non-immune" } \\
\text { antibody human } \\
\text { phage display } \\
\text { library, phage } \\
\text { display }\end{array}$ & mice & $\begin{array}{l}\text { (Sui et al., } \\
\text { 2009) }\end{array}$ \\
\hline & PN-SIA49 & stem (HA2) & $\lg G$ & & $\begin{array}{l}\text { Human, } \\
\text { peripheral B-cells, } \\
\text { Human modified } \\
\text { hybridoma }\end{array}$ & mice & $\begin{array}{l}\text { (De Marco et } \\
\text { al., 2012) }\end{array}$ \\
\hline & C179 & stem (HA1) & $\lg G 2 a$ & & mouse & mice & $\begin{array}{l}\text { (Lipatov et al., } \\
\text { 1997; Okuno et } \\
\text { al., 1993; Oku- } \\
\text { no et al., 1994; } \\
\text { Smirnov et al., } \\
\text { 2000); (Dreyfus } \\
\text { et al., 2013) }\end{array}$ \\
\hline $\begin{array}{l}\text { Influenza A } \\
\text { group } 2\end{array}$ & CR8020 & $\begin{array}{l}\text { fusion peptide } \\
\text { (HA2) }\end{array}$ & $\mathrm{mAb}$ & $\begin{array}{l}\text { prevents virion release } \\
\text { in the endosome and } \\
\text { inhibits the } \mathrm{HA} \mathrm{pH} \text {-in- } \\
\text { duced conformational } \\
\text { changes associated } \\
\text { with membrane fusion, } \\
\text { prevents HAO cleavage } \\
\text { by host protease }\end{array}$ & $\begin{array}{l}\text { Human, FACS } \\
\text { sorted memory } \\
\text { B-cells, Sorting } \\
\text { of immortalized } \\
\text { memory B-cells } \\
\text { stained with APC- } \\
\text {-labeled HA }\end{array}$ & mice & $\begin{array}{l}\text { (Ekiert et al., } \\
\text { 2011) }\end{array}$ \\
\hline
\end{tabular}




\begin{tabular}{|c|c|c|c|c|c|c|c|}
\hline \multirow{7}{*}{$\begin{array}{l}\text { H5N1 cross- } \\
\text { clade }\end{array}$} & $1 \mathrm{~B} 12,1 \mathrm{C} 9$ & $\begin{array}{l}\text { fusion peptide } \\
\text { (HA2) }\end{array}$ & & & $\begin{array}{l}\text { Mouse, splenocy- } \\
\text { tes, hybridoma }\end{array}$ & mice & $\begin{array}{l}\text { (Prabhu et al., } \\
\text { 2009a) }\end{array}$ \\
\hline & HAb21 & $\begin{array}{l}\text { conformational } \\
\text { epitope (HA1), }\end{array}$ & $\lg G 1$ & $\begin{array}{l}\text { probably by interfering } \\
\text { with viral binding }\end{array}$ & $\begin{array}{l}\text { Mouse, Splenocy- } \\
\text { tes, hybridoma }\end{array}$ & $\begin{array}{l}\text { positive in } \\
\text { pseudovi- } \\
\text { rus-based } \\
\text { neutraliza- } \\
\text { tion assay }\end{array}$ & $\begin{array}{l}\text { (Wu et al., } \\
\text { 2014) }\end{array}$ \\
\hline & $3 B 1$ & HA1 (2 epitops) & $\begin{array}{l}\text { Mouse } \\
\text { scFv: hu- } \\
\text { man IgG1 }\end{array}$ & & $\begin{array}{l}\text { Mouse, splenocy- } \\
\text { tes, hybridoma }\end{array}$ & mice & $\begin{array}{l}\text { (Prabhu et al., } \\
\text { 2009b) }\end{array}$ \\
\hline & FLA21.140, & $\begin{array}{l}\text { conformational } \\
\text { epitope proxi- } \\
\text { mal to the RBS } \\
\text { (HA1) }\end{array}$ & & & $\begin{array}{l}\text { Human, phage } \\
\text { display library } \\
\text { (Ph.D-12) }\end{array}$ & not done & $\begin{array}{l}\text { (Khurana et al., } \\
\text { 2009); (Velkov } \\
\text { et al., 2013) }\end{array}$ \\
\hline & $\begin{array}{l}3 \mathrm{C} 11 \\
4 \mathrm{C} 12, \\
3 \mathrm{H} 12,3 \mathrm{H} 4\end{array}$ & HA1 & mouse & & & $\begin{array}{l}\text { not done, } \\
\text { tested only } \\
\text { for virus } \\
\text { neutraliza- } \\
\text { tion }\end{array}$ & $\begin{array}{l}\text { (Du et al., } \\
\text { 2009) }\end{array}$ \\
\hline & 9F4, & $\begin{array}{l}\text { linear epitope } \\
\text { outside RBS } \\
\text { (HA1) }\end{array}$ & $\operatorname{lgG} 2 b$ & $\begin{array}{l}\text { blocks the HA pH-indu- } \\
\text { ced conformational } \\
\text { changes associated } \\
\text { with membrane fusion }\end{array}$ & $\begin{array}{l}\text { Mouse, splenocy- } \\
\text { tes, hybridoma }\end{array}$ & mice & $\begin{array}{l}\text { (Oh et al., } \\
\text { 2010) } \\
\text { (Velkov et al., } \\
\text { 2013) }\end{array}$ \\
\hline & AFlulgG01 & $\begin{array}{l}\text { membrane- } \\
\text {-distal globular } \\
\text { head (HA1) }\end{array}$ & $\begin{array}{l}\text { Human } \\
\text { FAb: Fc z } \\
\text { vectora } \\
\text { pAc-L-Fc }\end{array}$ & $\begin{array}{l}\text { inhibits binding to } \\
\text { sialyl-glycan receptors } \\
\text { and inhibits the HA } \\
\text { pH-induced conforma- } \\
\text { tional } \\
\text { changes associated } \\
\text { with membrane fusion }\end{array}$ & $\begin{array}{l}\text { Human, lym- } \\
\text { phocytes, phage } \\
\text { library }\end{array}$ & mice & $\begin{array}{l}\text { (Cao et al., } \\
2012 \text { ) } \\
\text { (Sun et al., } \\
\text { 2009) } \\
\text { (Velkov et al., } \\
2013 \text { ) }\end{array}$ \\
\hline $\begin{array}{l}\text { H1 cross- } \\
\text { clade }\end{array}$ & $\mathrm{CH} 65$ & RBS (HA) & $\begin{array}{l}\text { Vk:CL }+ \\
\text { VH: CH1-3 } \\
\text { of IgG1 }\end{array}$ & $\begin{array}{l}\text { reduction of the amo- } \\
\text { unt of viral particles } \\
\text { released into the su- } \\
\text { pernatant, reduction of } \\
\text { HA in the supernatant }\end{array}$ & $\begin{array}{l}\text { Human, plasmab- } \\
\text { last, screening } \\
\text { single sorted } \\
\text { plasmablast }\end{array}$ & & $\begin{array}{l}\text { (Whittle et al., } \\
\text { 2011) } \\
\text { (Brandenburg } \\
\text { et al., 2013) }\end{array}$ \\
\hline \multirow{2}{*}{ H3 subtype } & D1-8 & $\begin{array}{l}\text { conserved and } \\
\text { conformational } \\
\text { epitope of HA1 }\end{array}$ & scFv & & $\begin{array}{l}\text { Human, antibody- } \\
\text {-secreting plasma } \\
\text { cell (ASC) }\end{array}$ & $\begin{array}{l}\text { Mice (the- } \\
\text { rapeutic } \\
\text { 3dpi) }\end{array}$ & $\begin{array}{l}\text { (Benjamin et } \\
\text { al., 2014) }\end{array}$ \\
\hline & 12D1 & $\mathrm{HA} 2$ & $\lg G 1$ & & $\begin{array}{l}\text { Mouse, splenocy- } \\
\text { tes, hybridoma }\end{array}$ & $\begin{array}{l}\text { Mice (the- } \\
\text { raputic } \\
2 \text { dpi) }\end{array}$ & $\begin{array}{l}\text { (Wang et al., } \\
\text { 2010) }\end{array}$ \\
\hline \multirow{2}{*}{ Influenza B } & CR8033 & & $\begin{array}{l}\text { human } \\
\text { mAb }\end{array}$ & \multirow{2}{*}{$\begin{array}{l}\text { preventing virus pro- } \\
\text { geny release }\end{array}$} & \multirow{2}{*}{$\begin{array}{l}\text { Human, periphe- } \\
\text { ral B-cells, Phage } \\
\text { display }\end{array}$} & $\begin{array}{l}\text { Mice, HA1 } \\
\text { top of HA }\end{array}$ & \multirow{2}{*}{$\begin{array}{l}\text { (Dreyfus et al., } \\
\text { 2012) }\end{array}$} \\
\hline & CR8071 & $\begin{array}{l}\text { vestigial estera- } \\
\text { se domain }\end{array}$ & $\begin{array}{l}\text { human } \\
\text { mAb }\end{array}$ & & & Mice & \\
\hline
\end{tabular}

ous proteins of influenza virus (Mancini et al., 2011), two papers focused on broadly neutralizing antibodies (Clementi et al., 2012; Laursen \& Wilson, 2013), and an excellent review exploring the knowledge on the antigenic sites of H5 HA molecule (Velkov et al., 2013). The most interesting examples of such Abs are provided in Table 1 and some of them (sorted according to the target antigen) are shortly described below.

\section{Anti-Hemagglutinin}

Hemagglutinin (HA) is the major surface protein of influenza virus that forms homotrimers and plays a pivotal role in the virus infection cycle. As a major target of neutralizing Abs $\mathrm{HA}$ is under high evolutionary pressure, therefore it is the most variable protein of influenza virus. Eighteen different types of HA (H1-H18) are known, however $\mathrm{H} 17$ and $\mathrm{H} 18$ were found only in American fruit bats (Tong et al., 2013). HA subtypes were classified into two groups, group 1 including $\mathrm{H} 1$, H2, H5, H6, H8, H9, H11, H12, H13, H16, H17 and H18, and group 2 with H3, H4, H7, H10, H14 and H15.
Abs recognizing conserved epitopes within either globular or stem domains of hemagglutinin (HA) might have a neutralizing potential. Most antibodies against the globular domain of HA can be used as valuable diagnostic tools, however their broad therapeutic and prophylactic use is problematic (Mancini et al., 2011). The antigenic drift and the antigenic shift of the HA globular domain result in the limited specificity of antibodies recognizing epitopes located in this domain (Okada et al., 2010). In contrast, the stem domain of HA is highly conserved across multiple HA sub-types, thus it seems to be a more promising target for therapeutic antibodies. On the other hand, immunoglobulins against stem domain of HA represent only a small fraction of Abs raised by natural infections with influenza virus. The reason is poor immunogenicity of this domain which is less exposed on the virus surface than the HA head domain.

MAbs recognizing the globular domain demonstrate some cross-reactivity. For example, human mAb (mAb 5J8) isolated from a healthy person and targeting a conformational epitope adjacent to the shallow pocket of the receptor-binding site (RBS) is capable of neutralizing 
a broad spectrum of H1N1 viruses (Krause et al., 2011). Also, human mAb D1-8 that recognizes the proximal epitope but not within RBS, displays a neutralizing activity against diverse H3 viruses (Benjamin et al., 2014). Neutralizing Abs with much broader specificity and reacting with the globular domain of a variety of HA subtypes are quite rare. Such Abs seem to recognize small epitopes formed by the conserved elements of the RBS (Ekiert et al., 2012; Yoshida et al., 2009).

Various $\mathrm{mAbs}$ against the stem region of HA recognize distinct epitopes and display varying neutralizing potential and diverse mechanisms of antigen binding. Interestingly, it has been suggested (based on structural studies with three stem-binding mAbs: CR6261, F10 and FI6) that the use of CDR regions from both, $\mathrm{VH}$ and VL chains, is characteristic for naturally selected Abs, while the Abs selected by phage-display method bind to HA using only the $\mathrm{VH}$ encoded CDR(Corti et al., 2011). The cross-reactivity of neutralizing mAb CR6261 isolated from human peripheral blood mononuclear cells is limited to influenza A group 1 (Throsby et al., 2008). The potent therapeutic activity of CR6261 was demonstrated by $100 \%$ survival of mice that received a single $\mathrm{mAb}$ dose 4 days post infection (dpi). CR6261 binds via all three CDRs of heavy chain to the conformational epitope (F subdomain) within the stem region (Corti et al., 2011).

The $\mathrm{F}$ subdomain is also targeted by mAb FI6. This mAb displays quite a broad spectrum of crossreactivity; it is able to neutralize influenza A from both, group 1 (H1, H2, H5, H6, H8, and H9) and group 2 (H3, H4, H7, and H10) (Corti et al., 2011). FI6 showed prophylactic efficacy when administered at a dose of $4 \mathrm{mg}$ per $\mathrm{kg}$ of body weight and was partially protective at a dose of $2 \mathrm{mg} / \mathrm{kg}$. The therapeutic potential of FI6 was also confirmed in challenge experiments. All mice survived infection with A/Puerto Rico/8/34 (H1N1) when mAb F16 was administrated at a dose of $15 \mathrm{mg} / \mathrm{kg}, 1$ or $2 \mathrm{dpi}$. Binding to the $\mathrm{F}$ subdomain of $\mathrm{HA}$ increases $\mathrm{HA}$ stability, inhibiting the conformational changes necessary for membrane fusion. The FI6 Abs seem to have quite a high potential in medical and diagnostic applications.

Two other mAbs, CR8020 and CR9114, act through a similar mechanism of neutralization, namely they inhibit the membrane fusion by blocking pH-induced conformational changes of HA (Dreyfus et al., 2012; Ekiert et al., 2011). The CR8020 Ab potently neutralizes viruses from group 2 of influenza A, namely a wide spectrum of $\mathrm{H} 3 \mathrm{~N} 2$ and $\mathrm{H} 7 \mathrm{~N} 7$ and $\mathrm{H} 10 \mathrm{~N} 7$, while CR9114 has a much broader spectrum of reactivity and can neutralize not only influenza A but also $\mathrm{B}$ types of viruses. Interestingly, both antibodies compete with each other in HA binding which suggests that they recognize the same epitope (Dreyfus et al., 2012). Moreover, CR9114 recognizes a nearly identical epitope to that of CR6261 and the mechanism of binding is similar (three CDRs of heavy chain). Therapeutic treatment with $15 \mathrm{mg} / \mathrm{kg}$ of CR8020 completely prevented mortality caused by $\mathrm{H} 3 \mathrm{~N} 2$ up to 2 dpi. Similar dose of CR9114 was sufficient to protect animals from influenza $A$ and $B$ infections. Therapeutic potential of CR8020 has been tested in clinical trials (see below).

As described by other researchers, 1C9 mAb binds to an antigenically conserved linear epitope GLFGAIAGF, situated in the HA2 fusion peptide (Prabhu et al., 2009). Experiments with the use of a mouse model confirmed $100 \%$ protection against $\mathrm{H} 5 \mathrm{~N} 1$ viruses from clade 1 and
2 when administered $1 \mathrm{dpi}$, and 50\% protection when administered 3 dpi. These antibodies were also effective as a prophylactic therapy when administered 1 day before challenge.

Mechanisms of HA-targeted influenza virus neutralization by several previously described neutralizing anti-HA antibodies binding to known epitopes, were recently investigated by using live cell imaging and infecting viruses (Brandenburg et al., 2013). Results of this study allowed to distinguish four physiologically relevant mechanisms, by which these antibodies interfere with the pivotal functions of HA, namely receptor binding, membrane fusion, HA0 cleavage and egress of newly synthesized viruses. The HA head domain-binding Abs either interfere with attachment of the influenza virus to its cellular receptor (e.g. $\mathrm{mAb}$ CR8033) or inhibit viral egress (e.g. mAb CR8071) resulting in reduction of the amount of viral particles released from the infected cells. Antibodies against the stem (e.g. mAbs CR6261, CR8020) overlap with the fusion peptide and inhibit membrane fusion. Alternatively, they can bind close to the cleavage site and prevent cleavage of HA0 into HA1 and HA2. As a consequence, conformational changes of HA, which are essential for infection, are inhibited. This mechanism of virus neutralization (inhibiting the membrane fusion) does not decrease the amounts of viral particles released from the cell but causes the released particles to be non-infectious.

\section{Anti-Neuraminidase}

Neuraminidase (NA) is the second most abundant influenza glycoprotein that is localized in the external viral membrane, and it exists as a homotetramer. It is less variable than HA, but it also has a tendency to undergo antigenic shift and antigenic drift. Anti-NA Abs do not neutralize the virus infectivity but they limit the infection by impairing the efficient release of the virus from infected cells, which hampers virus shedding, thus reducing severity of the illness (Mancini et al., 2011). Four antigenic sites were identified on NA. Some anti-NA Abs inhibit the sialidase activity of NA and, in consequence, block viral release from the host cell (Gamblin \& Skehel, 2010). They can also reinforce anti-influenza virus response by evoking ADCC (Mozdzanowska et al., 1999).

Two broadly cross-reactive NA-specific mAbs (1H5 and $3 \mathrm{H} 10$ ) interacting with conserved conformational epitope were recently demonstrated to possess a prophylactic efficacy in mice (Wan et al., 2013). Interesting results were also reported for $\mathrm{mAb}$ targeting the highly conserved linear epitope of NA (ILRTQESE/SC located between amino acids 222-230). These Abs were able to inhibit all nine types of NA in vitro and provided a hetero-subtypic protection in mice challenged with mouseadapted $\mathrm{H} 1 \mathrm{~N} 1$ and $\mathrm{H} 3 \mathrm{~N} 2$, representing group 1 and 2 viruses, respectively (Doyle et al., 2013). In contrast, regular administration of other anti-NA mAb, $2 \mathrm{~B} 9$, to mice and ferrets resulted only in $50 \%$ protection in both animal species against A/Vietnam/1203/04(H5N1) virus (Shoji et al., 2011).

\section{Anti-M2 protein}

The M2 protein is located in viral envelope and forms a homotetrameric proton-selective channel, active in acidic pH (Iwatsuki-Horimoto et al., 2006). Extracellular part of M2 (M2e) is strongly conserved among all influenza A viruses. Therefore, despite its poor immunogenic 
ability and absence of anti-M2e Abs during a natural infection, it is a promising candidate for broadly-reactive Abs (Mancini et al., 2011). Anti-M2e mAbs do not have neutralization activities but they can reduce virus replication by ADCC and CDC (Wang et al., 2008). Human M2-specific mAb TCN-032 had therapeutic activity against $\mathrm{H} 5 \mathrm{~N} 1$ in vivo and significantly reduced mortality in case of mice challenge with H1N1 (Grandea et al., 2010). Binding of $\mathrm{Ab}$ to the highly conserved N-terminal part of $\mathrm{M} 2 \mathrm{e}$ also seems to restrict the virus escape. Therapeutic potential of TCN-032 is being tested in clinical trials (see below).

It is worth to note that mAb D005 had prophylactic and therapeutic activities in vivo in mice infected with mouse-adapted virus A/Puerto Rico/8/1934 (H1N1), when administered as either human $\mathrm{scFv}$ fused to the mouse $\mathrm{Fc}-\gamma 2 \mathrm{c}$ domain or as human $\operatorname{IgG} 1 x$ antibody (Beerli et al., 2009).

\section{Anti-Internal proteins}

Other proteins of influenza virus, because of their internal character, do not interact directly with Abs and do not induce production of virus neutralizing Abs. However, they might increase viral clearance by mechanisms such as those reported for anti-NP induction of CDC (Yewdell et al., 1981) or by increase of the $T$ cell response (Thomas et al., 2006). It was also demonstrated that MDCK cells expressing anti-PB2 mAb 143/3 became resistant to $\mathrm{H} 5 \mathrm{~N} 3$ infection, probably by blocking viral transcription (Fujimoto et al., 2013). It is worth to mention that PEN-HuScFv, an anti-M1 scFv fused to a penetration peptide from Drosophila, was able to inhibit binding of M1 (a highly conserved protein, involved in viral replication) to RNA and reduced the amount of viral particles released from the infected cell (Poungpair et al., 2009).

\section{SELECTION OF ANTIBODIES USEFUL IN ANTI-INFLUENZA TREATMENT}

The choice of the isolation method is crucial for properties of the resulting Abs. Three very important decisions to be considered during the design stage of such experiments include: (i) a type of donor(s) species or cells, (ii) an organ used as a source of $\mathrm{Ab}$ or its gene and (iii) a selection technique (Fig. 2).

Type of donor and source of antibody and its gene

Although genetic manipulation permits for large variations among the selected Abs, every species has some preferences in codon usage or type of synthesized Abs, thus decision concerning donor species can be crucial to final results. Because the mice immune system is well described, the first monoclonal antibodies were obtained in this species. Still, many of therapeutic mAbs are of murine origin. Unfortunately, repeated administration of murine antibodies can cause human anti-mouse antibody reaction, thus their usage in clinical applications is limited (Schirrmann et al., 2011). However, some of them are accepted by FDA (U.S. Food and Drug Administration) (Brekke \& Loset, 2003). In order to minimize the side effects of murine Abs, chimeric and humanized Abs

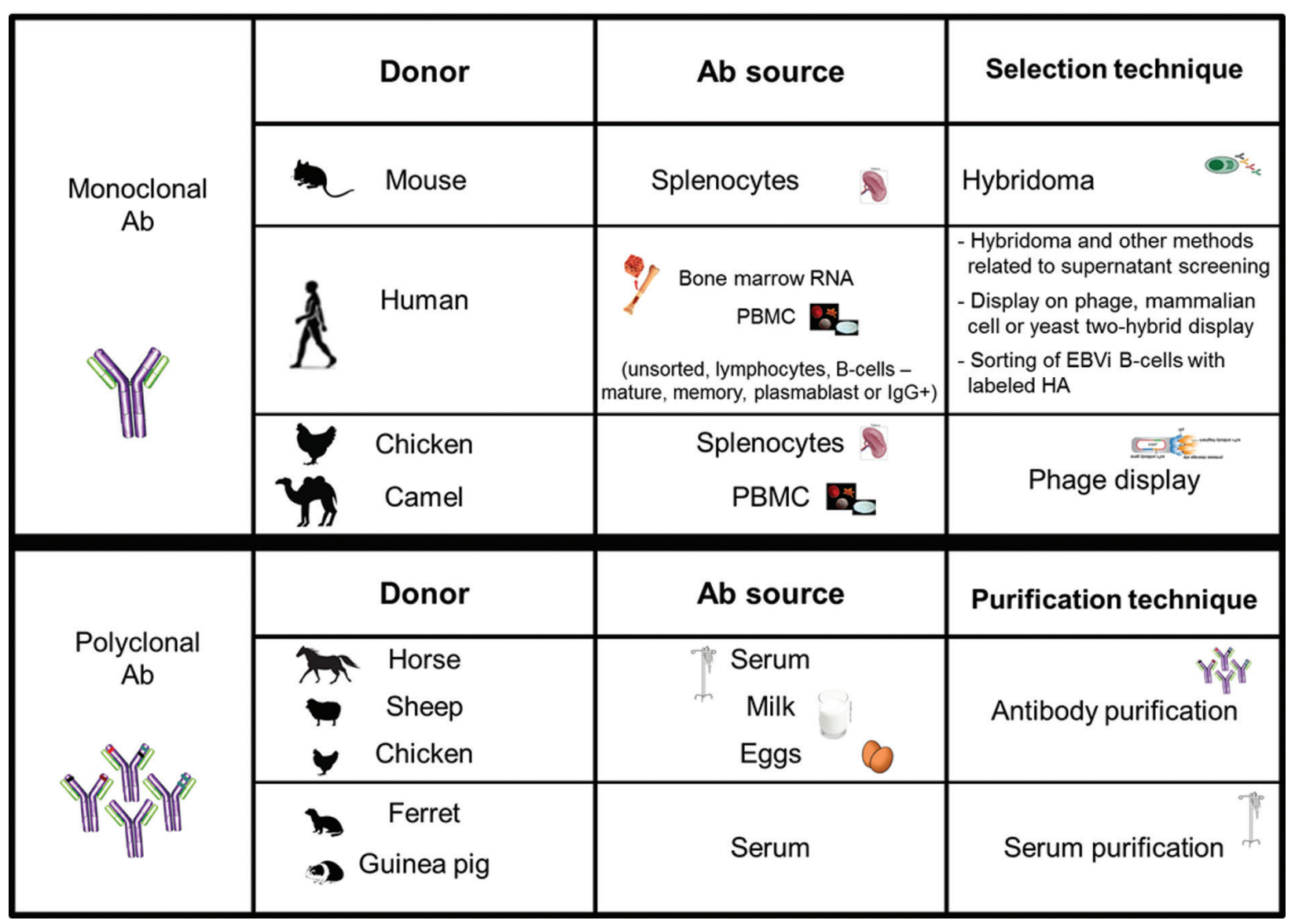

Figure 2. Scheme of the methods used for anti-influenza antibody isolation. PBMC, peripheral blood mononuclear cells, EBVi, Epstain Barr virus immortalized; HA, hemagglutinin. 
were created and approved. Moreover, transchromosomic mice engineered to produce solely human-type Abs are already in use (Wang et al., 2008). If a mouse donor is to be used, splenocytes and hybridoma selection techniques are generally applied (Wu et al., 2014; Yoshida et al., 2009; Zebedee \& Lamb, 1988).

Modern technologies allow researchers to isolate human mAbs from bone marrow (Ekiert et al., 2012; Kashyap et al., 2008) or from peripheral B-cells (Beerli et al., 2009; Dreyfus et al., 2012; Thathaisong et al., 2008). Promising results concerning influenza virus neutralization were obtained for several other donor species, including horse (Herbreteau et al., 2014), chicken (Pitaksajjakul et al., 2010; Wallach et al., 2011), camel (Tillib et al., 2013); sheep (Rinaldi et al., 2014; Simmons et al., 2007); ferret (Fang et al., 2012) and guinea pig (Howard et al., 2011).

The $\mathrm{pAb}$ preparations from human serum have a long history of effectiveness. There are two main methods of artificial passive immunization against influenza for humans, namely convalescent plasma or intravenous immunoglobulin preparations made from pooled human plasma (Hui et al., 2013). If suitable donors are available, passive immunotherapy with convalescent plasma or with hyperimmune globulin prepared from convalescent plasma is a good option to treat severe influenza. However, when such donors are not available, intravenous immunoglobulin preparations which are manufactured in consecutive series reflecting immune status of a population remain an interesting alternative (Kubota-Koketsu et al., 2012). Efficiency of convalescent plasma was described by meta-analysis provided by Luke and co-workers (Luke et al., 2006), who reported that during $1918 \mathrm{H} 1 \mathrm{~N} 1$ pandemic there was an overall reduction in mortality from $37 \%$ to $16 \%$ after such a treatment. Case study for H5N1 influenza treatment with convalescent plasma was also reported (Zhou et al., 2007). Recently, two clinical trials with convalescent plasma and hyperimmune IV immunoglobulin (H-IVIG) treatment have been described (see the Clinical trials chapter).

If a donor is an animal, usually some kind of immunization protocol is used (Wang et al., 2008; Wu et al., 2014; Zebedee \& Lamb, 1988). In case of a human donor, antibodies against influenza were obtained from vaccinated subjects (Dreyfus et al., 2012; Ekiert et al., 2011; Throsby et al., 2008), convalescents ( $\mathrm{Hu}$ et al., 2012; Kashyap et al., 2008; Sun et al., 2009) and from defined populations, for example people born in 1915 or earlier (Yu et al., 2008), described also as a 1918 pandemic survivors (Mancini et al., 2011) or designated as "non-immune", which means that no special effort has been done to increase or measure the influenza-specific Abs titer of donors (Lim et al., 2008; Thathaisong et al., 2008). Additionally, some ready to use (usually "nonimmune") libraries, like an Ab phage display library (Sui et al., 2009) or intrabodies library (Mukhtar et al., 2009) were screened for Ab fragments neutralizing influenza viruses. Material for Ab screening can be collected either from a single individual (Beerli et al., 2009; Krause et al., 2011; Liu et al., 2004) or it can be pooled from a few or even tens of donors (Herbreteau et al., 2014; Simmons et al., 2007; Sui et al., 2004; Thathaisong et al., 2008; Yoshida et al., 2009).

\section{Polyclonal antibodies}

pAbs purification techniques depend mostly on the used source. While many mammalian Abs are bound by protein A, G and L, main Abs of chicken eggs, IgY, do not, and have to be purified in other ways.

Before the development of molecular technologies, serum transfusions from immunized animals or from convalescents were used for treatment of severe diseases. However, one should remember that such serum could contain potentially harmful pathogens and factors causing anti-serum response of the recipient immune system. Challenge experiments in mice confirmed the protective effects of hyperimmune antiinfluenza serum from ferrets (Fang et al., 2012), sheep (Simmons et al., 2007), chicken (Shahzad et al., 2008) and guinea pig (Howard et al., 2011).

Polyclonal immunoglobulins and their fragments from different organism have been used in passive immunization experiments. Two recent examples of such pAb-based approaches include highly purified equine specific $\mathrm{F}(\mathrm{ab})_{2}$ against $\mathrm{H} 5 \mathrm{~N} 1$, also named Fabenflu (Herbreteau et al., 2014) and ovine polyclonal IgG purified with protein $G$ from lactating ewes (Rinaldi et al., 2014), both very effective in mice protection against influenza virus. It is also worth to mention the successful examples of using influenza-specific $\operatorname{IgY}$ from chicken egg yolks in mice challenge experiments; this inexpensive and simple technique of $\mathrm{pAb}$ production and purification has many advantages ( $\mathrm{Xu}$ et al., 2011). At least two independent groups were able to demonstrate in mice models high cross-reactive potential of anti-H5N1 and anti-H1N1 IgY extracted from eggs of hens immunized with the inactivated H5N1 (Wallach et al., 2011; Yang et al., 2014).

\section{Monoclonal antibodies}

Several selection techniques resulting in successful isolation of broadly neutralizing anti-influenza antibodies are presented below.

\section{Hybridoma}

Hybridoma is the oldest techniques enabling to obtain a relatively stable cell line producing desirable $\mathrm{mAb}$. During the standard hybridoma procedure Ab-producing mice splenocytes are fused with immortal myeloma cells, then the resulting aneuploid cell line supernatant is screened against a given antigen, which is followed by hybridoma cell cloning on agar or by limiting dilutions and re-screening (Lerner, 1981). This technique has proven to be useful for producing Abs against M2 (Fu et al., 2009; Liu et al., 2004; Zebedee \& Lamb, 1988), HA1 (Du et al., 2009; Oh et al., 2010) and fulllength HA of subtypes H1, H2, H3 and H13 (Yoshida et al., 2009). More recently, anti-HA neutralizing Abs were isolated with a modified hybridoma technique. One type of those modifications uses the Epstein-Barr virus immortalized (EBVi) human B cells (Clementi et al., 2011; De Marco et al., 2012; Krause et al., 2010); second EBVi PBMC and human B cells fused to myeloma (Krause et al., 2011). Those techniques allowed for selection of 2D1 and 2B12 mAbs with neutralizing activity against both, 1918 and 2009 pandemic strains (Krause et al., 2010), mAb 5J8 recognizing a conserved non-linear epitope (residues 133, 137 and 222) on the globular head of H1N1 HA (Krause et al., 2011) as well as a broad specificity mAb such as PN-SIA49 that recognizes conserved epitopes located on the stem region of HA (De Marco et al., 2012) and PN-SIA-28 (Clementi et al., 2011) that is able to neutralize influenza viruses $\mathrm{A}$ of groups 1 and 2 . 
Other methods related to supernatant screening

A technique similar to hybridoma but using non immortalized B-cell lines was used to obtain broadly neutralizing HA-specific Abs (Corti et al., 2011). Supernatants of single plasma cell cultures in a medium supplemented with interleukin 6 (IL-6) were screened with multiple parallel binding assays and cDNA of the selected $\mathrm{Abs}$ were rescued by single-cell reverse transcription polymerase chain reaction (RT-PCR). Single cell RT-PCR was also used by other teams to obtain cDNA sequence of Abs broadly neutralizing H1N1 viruses, however in these cases the cDNA libraries were created and screen- ing of Abs produced by transfected 293T cells (Whittle et al., 2011) or 293A (Wrammert et al., 2011) was performed.

Phage display

Phage display has been used for years and it remains the gold standard for recombinant Abs production (Hairul Bahara et al., 2013). This technique consists of construction of a library expressing peptides or proteins as fusions with phage capsid protein which permits to find phages with proteins interacting with a given DNA, peptides or proteins. The cDNA fragments encod-

Table 2. Monoclonal and polyclonal antibody preparations in clinical trials according to Cinicaltrials.gov database [http://clinicaltrials. gov]).

\begin{tabular}{|c|c|c|c|c|c|}
\hline $\begin{array}{l}\text { Responsible } \\
\text { party }\end{array}$ & $\begin{array}{l}\text { Material te- } \\
\text { sted }\end{array}$ & Trial ID & Purpose & $\begin{array}{l}\text { Phase } \\
\text { /Status* }\end{array}$ & Results (if known) \\
\hline \multicolumn{6}{|c|}{ Monoclonal antibody preparations } \\
\hline \multirow{4}{*}{$\begin{array}{l}\text { Crucell Hol- } \\
\text { land BV }\end{array}$} & CR8020 & NCT01938352 & $\begin{array}{l}\text { To compare prophylactic efficacy aga- } \\
\text { inst H3N2, safety, tolerability, pharma- } \\
\text { cokinetics, and potential immunogeni- } \\
\text { city of CR8020 vs. placebo. }\end{array}$ & $2 / C$ & Completed March 2014. \\
\hline & CR8020 & NCT01756950 & $\begin{array}{l}\text { To compare the safety, tolerability, } \\
\text { pharmacokinetics and immunogenicity } \\
\text { of single escalating doses of CR } 8020 \text { vs. } \\
\text { placebo in healthy subjects. }\end{array}$ & $1 / \mathrm{C}$ & Antibody admitted to Phase 2. \\
\hline & CR6261 & NCT01406418 & $\begin{array}{l}\text { To compare the safety, tolerability, } \\
\text { pharmacokinetics and immunogenicity } \\
\text { of single escalating doses of CR6261 vs. } \\
\text { placebo in healthy subjects. }\end{array}$ & $1 / C$ & $\begin{array}{l}\text { Antibody initially admitted to } \\
\text { Phase } 2 \text {. }\end{array}$ \\
\hline & $\begin{array}{l}\text { CR8020 and } \\
\text { CR6261 }\end{array}$ & NCT01992276 & $\begin{array}{l}\text { To evaluate the rate of decline in quan- } \\
\text { titative viral load measured in hospitali- } \\
\text { zed patients with influenza A infection. }\end{array}$ & $2 / \mathrm{W}$ & $\begin{array}{l}\text { Withdrawn prior to enrollment } \\
\text { due to preliminary efficacy } \\
\text { results from an influenza chal- } \\
\text { lenge trial. }\end{array}$ \\
\hline \multirow{2}{*}{$\begin{array}{l}\text { Theraclone } \\
\text { Sciences, Inc. }\end{array}$} & TCN-032 & NCT01719874 & $\begin{array}{l}\text { To compare safety and efficacy of TCN- } \\
032 \text { vs. placebo given to healthy adult } \\
\text { volunteers that have been inoculated } \\
\text { with the influenza A virus. }\end{array}$ & $2 / R P$ & $\begin{array}{l}\text { Estimated study completion } \\
\text { date was March 2013, but re- } \\
\text { cruitment is still ongoing. }\end{array}$ \\
\hline & TCN-032 & NCT01390025 & $\begin{array}{l}\text { To compare the safety profile of a sin- } \\
\text { gle intravenous administration of TCN- } \\
032 \text { vs. placebo in healthy volunteers. }\end{array}$ & $1 / C$ & Antibody admitted to Phase 2. \\
\hline Visterra, Inc. & VIS410 & NCT02045472 & $\begin{array}{l}\text { To assess the safety, tolerability, im- } \\
\text { munogenicity and pharmacokinetics } \\
\text { of single escalating doses of VIS410 in } \\
\text { healthy volunteers. }\end{array}$ & $1 / \mathrm{NB}$ & \\
\hline $\begin{array}{l}\text { Functional } \\
\text { Genetics Inc. }\end{array}$ & FGI-101-1A6 & NCT01299142 & $\begin{array}{l}\text { To determine the safety and tolerability } \\
\text { of the anti-TSG101 human monoclonal } \\
\text { antibody (FGI-101-1A6) administered to } \\
\text { healthy volunteers. }\end{array}$ & $1 / \mathrm{U}$ & \\
\hline \multicolumn{6}{|c|}{ Polyclonal antibody preparations } \\
\hline \multirow{2}{*}{$\begin{array}{l}\text { The University } \\
\text { of Hong Kong }\end{array}$} & $\begin{array}{l}\text { Plasma treat- } \\
\text { ment }\end{array}$ & NCT01306773 & $\begin{array}{l}\text { Patients with severe } 2009 \text { pdm H1N1 } \\
\text { infection treated with antivirals were } \\
\text { offered treatment with plasma with a } \\
\text { neutralizing antibody titer of } \geq 1: 160 \text {, } \\
\text { harvested from patients recovering } \\
\text { from the } 2009 \text { pdm H1N1 infection. } \\
\text { Clinical outcome was compared with } \\
\text { that of patients who declined plasma } \\
\text { treatment after matching patients by } \\
\text { age, sex, and disease severity scores. }\end{array}$ & $\mathrm{NP} / \mathrm{C}$ & $\begin{array}{l}\text { Mortality and temporal levels } \\
\text { of IL-6, IL-10, and TNF-a were } \\
\text { lower in the plasma treatment } \\
\text { group. }\end{array}$ \\
\hline & $\begin{array}{l}\text { H-IVIG Treat- } \\
\text { ment }\end{array}$ & NCT01617317 & $\begin{array}{l}\text { Patients with severe } 2009 \text { pdm H1N1 } \\
\text { infection on standard antiviral treat- } \\
\text { ment, requiring intensive care and } \\
\text { ventilatory support were randomized } \\
\text { to receive H-IVIG (hyperimmune intra- } \\
\text { venous immunoglobulin) fractionated } \\
\text { from patients who recovered from the } \\
2009 \text { pdm H1N1 or normal IV immuno- } \\
\text { globulin manufactured before } 2009 \text { as } \\
\text { control. }\end{array}$ & $\mathrm{NP} / \mathrm{C}$ & $\begin{array}{l}\text { H-IVIG treatment was the only } \\
\text { factor that independently re- } \\
\text { duced mortality. This treatment } \\
\text { was associated with significan- } \\
\text { tly lower post-treatment viral } \\
\text { load. The initial serum cytokine } \\
\text { level was significantly higher } \\
\text { in the H-IVIG group but fell } \\
\text { to a similar level } 3 \text { days after } \\
\text { treatment. }\end{array}$ \\
\hline
\end{tabular}




\begin{tabular}{|c|c|c|c|c|}
\hline \multirow{6}{*}{$\begin{array}{l}\text { National Insti- } \\
\text { tute of Allergy } \\
\text { and Infectious } \\
\text { Diseases (NI- } \\
\text { AID) }\end{array}$} & $\begin{array}{l}\text { Pharmaco- } \\
\text { kinetics of } \\
\text { H-IVIG }\end{array}$ & NCT02008578 & $\begin{array}{l}\text { To determine the pharmacokinetic } \\
\text { profile of Flu-IVIG (a type of H-IVIG) and } \\
\text { assess whether antibody levels obse- } \\
\text { rved following Flu-IVIG transfusion are } \\
\text { similar to those predicted in individuals } \\
\text { with influenza A or B. }\end{array}$ & $1 / 0$ \\
\hline & $\begin{array}{l}\text { H-IVIG prepa- } \\
\text { ration study }\end{array}$ & NCT00383071 & $\begin{array}{l}\text { To determine how best to use a vacci- } \\
\text { ne for generating high levels of H-IVIG } \\
\text { in people, which can be then collected } \\
\text { and used to develop a possible treat- } \\
\text { ment for avian influenza. }\end{array}$ & $2 / 0$ \\
\hline & $\begin{array}{l}\text { Plasma col- } \\
\text { lection/ pre- } \\
\text { parations }\end{array}$ & NCT01136057 & $\begin{array}{l}\text { To collect blood samples from people } \\
\text { who have been exposed to the influ- } \\
\text { enza virus and/or who have received a } \\
\text { seasonal influenza vaccine. The blood } \\
\text { plasma will be processed into fresh } \\
\text { frozen plasma and used in a future } \\
\text { clinical trial to treat people hospitalized } \\
\text { with influenza. }\end{array}$ & $\mathrm{NP} / \mathrm{O}$ \\
\hline & $\begin{array}{l}\text { Plasma col- } \\
\text { lection }\end{array}$ & NCT00984451 & $\begin{array}{l}\text { To collect plasma samples from people } \\
\text { who have high levels of antibodies aga- } \\
\text { inst the influenza A virus because they } \\
\text { either have been previously infected } \\
\text { with the virus or have been vaccinated } \\
\text { against the infection. }\end{array}$ & $\mathrm{NP} / \mathrm{O}$ \\
\hline & $\begin{array}{l}\text { Pharmaco- } \\
\text { kinetics of } \\
\text { H-IVIG }\end{array}$ & NCT02037282 & $\begin{array}{l}\text { To evaluate safety, tolerability and the } \\
\text { pharmacokinetics of an anti-influenza } \\
\text { H-IVG. }\end{array}$ & $1 / \mathrm{RP}$ \\
\hline & $\begin{array}{l}\text { Plasma treat- } \\
\text { ment }\end{array}$ & NCT01052480 & $\begin{array}{l}\text { To compare the safety, efficacy, and } \\
\text { pharmacokinetics of anti-influenza pla- } \\
\text { sma vs. standard care in hospitalized } \\
\text { participants with H1N1 or H3N2 infec- } \\
\text { tion at risk of severe disease. }\end{array}$ & $2 / \mathrm{RP}$ \\
\hline $\begin{array}{l}\text { Shanghai } \\
\text { Public Health } \\
\text { Clinical Center }\end{array}$ & $\begin{array}{l}\text { Blood fix } \\
\text { treatment }\end{array}$ & NCT01055990 & $\begin{array}{l}\text { To treat critical H1N1 patients with } \\
\text { blood fix and further observe the effec- } \\
\text { tiveness and safety. }\end{array}$ & $2 / U$ \\
\hline
\end{tabular}

C, completed; W, withdrawn; RP, recruiting participants; NB, not yet begun; U - status unknown; NP, without designated Phase; O, ongoing

ing such peptides or proteins are inserted as a part of phage's genetic material, and their nucleotide sequence can be easily determined. Usually, this procedure is used to clone scFv (Schirrmann et al., 2011). Phage display succeeded in selection of many broadly neutralizing human anti-HA mAbs (Dreyfus et al., 2012; Ekiert et al., 2012; Kashyap et al., 2008; Sui et al., 2009; Throsby et al., 2008). Also, influenza-neutralizing chicken Fab (Pitaksajjakul et al., 2010) and camel VHH (Tillib et al., 2013) have been obtained by this technique. The phage display library can be used not only for isolation of Abs but also for epitope's mapping (Khurana et al., 2009; Wu et al., 2014). A technique called an in vivo phage display is known since 1996 (Babickova et al., 2013).

\section{Yeast two-hybrid display}

Yeast Gal4 transcription activator protein is an endogenously expressed yeast protein consisting of the DNA binding domain (BD) and the activation domain (AD). The $\mathrm{BD}$ and $\mathrm{AD}$ domains can be physically separated and synthesized as chimeric proteins fused with other proteins ( $\mathrm{X}$ and $\mathrm{Y}$, respectively). If interaction between the partner proteins ( $\mathrm{X}$ and $\mathrm{Y}$ ) occurs, it brings the separate $\mathrm{AD}$ and $\mathrm{BD}$ domains in close proximity, thereby reconstituting the function of Ga14 and driving expression of a downstream reporter gene (Young, 1998). This system was used to obtain Abs targeting the nucleoprotein of influenza virus (Mukhtar et al., 2009). Nucleoprotein gene was inserted into pGBKT7 to create a protein containing the GAL4 DNA-binding domain fused to the NP protein, which was used as a bait. Intrabodies'
cDNA fragments were inserted into pSF50, and then library plasmids were transformed into yeast AH109 cells harboring the bait plasmid. Transformed AH109 cells were grown on a highly selective medium. Single colonies were isolated and transferred onto the QDO medium with $\mathrm{X}-\alpha-\mathrm{Gal}$. Blue clones were identified as positive clones indicating interaction between antigen (NP) and the $\mathrm{Ab}$ fragments.

\section{Mammalian cell display}

Mammalian cell display based on the Sindbis virus expression system was used for selection of Abs recognizing the M2e protein (Beerli et al., 2009). Briefly, in this technique the $\mathrm{scF}_{\mathrm{v}}$ library from B-cells was prepared in a plasmid allowing for cell surface localization of the recombinant proteins, used for cell transfection. Infected cells were tested by FACS (Fluorescence Activated Cell Sorting) analysis for M2-binding to identify virus clones encoding M2-specific scFv antibodies.

Sorting of immortalized memory B-cells stained with allophycocyanin (APC)-labeled HA

Supernatant screening methods usually require testing of large amount of cells; for example 104000 plasma cells were tested by Corti and co-workers (Corti et al., 2011). A very fast method of Abs screening, based on sorting B cells stained with labeled HA was developed and successfully used to identify anti-HA mAbs (Ekiert et al., 2011). It is worth to mention that mAb CR8020 selected by this method were already tested in Phase 2 clinical trials (see Table 2 and the Clinical Trials chapter). 


\section{VERIFICATION OF THE EFFICACY OF ANTI-INFLUENZA ANTIBODIES}

Determination of the epitope recognized by $\mathrm{mAb}$ gives an important hint for evaluation of its neutralizing activity, especially in the case of Abs against proteins with such well characterized antigenic properties as influenza HA. Nevertheless, even if this epitope is known, the mechanism of neutralization of an antigen might be complex and might be a combination of direct and indirect mechanisms. Because some of them depend on the presence of $\mathrm{Fc}$ fragments, differences in virus neutralization by $\mathrm{Ab}$ fragments and full-length $\mathrm{Abs}$ can be expected (Edwards \& Dimmock, 2000). Several in vitro and in vivo methods can be used for examination of the efficiency of $\mathrm{Ab}$ binding and for evaluation of $\mathrm{Ab}$ usefulness in virus neutralization.

\section{In vitro methods}

\section{Hemagglutination inhibition (HI)}

This test depends on natural ability of some viruses (such as influenza virus) to agglutinate red blood cells upon binding to their surface. Incubation of the HA antigen or the entire virus with Abs binding to the receptor binding site of HA will inhibit this process (Brandenburg et al., 2013). Despite theoretical simplicity this test is not fully reliable. It is strongly dependent on subjective assessments, laboratory conditions and other factors, which can introduce some errors (Defang et al., 2012).

\section{Microneutralization (MN)}

The theoretical assumption of this test is very similar to the HI test. This highly sensitive and specific test depends on the presence of virus neutralizing Abs in the sample added to the cell culture (e.g. MDCK). The examined Abs or sera are pre-incubated with standardized amounts of the respective virus before its addition to the cells. Subsequently, the ELISA test is used to measure the presence of NP in the infected cells (WHO, 2013).

\section{In vivo methods}

This group of methods reflects more accurately immunological reactions of an organism during a viral infection. Challenge with the virus is an unambiguous and the most important test. Each step of such tests should be well justified because of the associated ethical issues and the significant costs. An appropriate animal model has to be chosen depending on the virus strain used and its natural host (Bouvier \& Lowen, 2010). Such clinical signs as weight loss, histopathological changes and viral load in tissues (nasopharynges or lung) can be assessed, depending on the animal model. Passive immunization, namely administration of neutralizing Abs combined with challenge with the chosen virus proves most clearly the efficacy and the neutralizing possibilities of the applied Abs. Several animal models are commonly used in immunization study against influenza virus.

Mouse (Mus musculus) is commonly used in drug development and challenge experiments. The main advantages are: relatively low cost, high availability, ability of gene manipulations and generally available species-specific reagents. The main disadvantages, from the viewpoint of anti-influenza vaccine efficacy confirmed by challenge, is the lack of typical for humans sialic acid receptors with an $\alpha-2,6$ linkage to galactose. Without prior adaptation to the mice model, it causes resistance of mice to human influenza viruses.

Ferrets (Mustela putorius) are the most representative small animals for human influenza disease model. This influenza susceptible animal has few disadvantages, including the relatively large size, high cost of breeding and husbandry requirements. Its main advantage is similarity of influenza virus infection symptoms in ferrets and humans. Ferrets were used as a model for an antiviral drug (olsetamivir, amantadine) and in a virus transmission study.

Guinea Pigs (Cavia porcellus), similarly to ferrets, are highly susceptible to human influenza virus. However, in this model a high level of viral titer does not correlate with disease severity (which is always weaker). Moreover, virus infection does not spread throughout the organism and is limited to the respiratory tissues.

Nonhuman Primates. Rhesus macaques (Macaca mulatta) are the most genetically similar to a human animals but this model is usually involved only in the most complicated studies, such as tests of antiviral drugs, vaccine efficacy and examination of gene expression during virus infection. More details about animal models used in research related to influenza can be found elsewhere (Bouvier \& Lowen, 2010).

Besides conventional immunization methods based on administration of an antigen (active immunization) or a specific Abs (passive immunization) other experimental methods were effective in obtaining protection against influenza viruses. One of these methods, called vectored immunoprophylaxis (VIP), is based on usage of adeno-associated virus (AAV) expressing Abs recognizing the epitope mapped in the HA stem region (Balazs et al., 2013). The authors cloned the cDNA fragments encoding VH and VL of previously characterized neutralizing mAbs (F10 and CR6261) into the AAV-based expression vector containing the $\mathrm{Fc}$ of a human IgG1. Next, the efficacy of the VIP method was tested in a mice model. Within 1 week, a single dose (1x10 ${ }^{11}$ genome copies) of recombinant AAV resulted in generation of a detectable level of human $\mathrm{IgG}$ in the serum. Expected specificity was confirmed in the HI test. What is worth to note, mice that received recombinant AAV bearing the F10 sequence were fully protected against the H1N1 challenge. Unfortunately, the test in ferrets gave much less promising results. The Abs level was 100-fold lower than in mice and no protection was observed in the challenge experiments (Balazs et al., 2013). Another example of a similar approach was reported for mice that were tested in passive immunization with a recombinant adenovirus expressing anti-HA H5-specific single-domain Ab (Tutykhina et al., 2013). Instead of the classic $\mathrm{scFv}_{\mathrm{v}}$, the camelid single-domain antibody (sdAb) was used. Intranasal administration protected mice that received sdAbs 14 days before the challenge, against challenge with $\mathrm{H} 5 \mathrm{~N} 2$ virus. Moreover, combination of adenovirus-expressed $\mathrm{sdAb}$ and the recombinant $\mathrm{sdAb}$ purified from the bacterial expression system indicated a protective property of this approach in both prophylactic and therapeutic applications (Tutykhina et al., 2013). In a similar approach mice were vaccinated with a plasmid encoding full-length $\mathrm{Ab}$ isolated from hybridoma cells (Yamazaki et al., 2011). Experimental infection with $\mathrm{H} 1 \mathrm{~N} 1$ (A/PR/8/34 strain) that was performed 20 days after intramuscular plasmid administration (in 3 muscles) resulted in 100\% protection (Yamazaki et al., 2011). 
It is worth to mention that some Abs have the virus neutralizing activity only in vivo. Neutralization of influenza virus by such Abs requires interaction between the Fc fragment and Ab Fc receptor for $\mathrm{IgG}$ suggesting that the mechanism of their neutralizing activity is based on induction of ADCC (DiLillo et al., 2014).

\section{Clinical trials (http://clinicaltrials.gov/)}

The ClinicalTrials.gov database [http://clinicaltrials. gov] contains information about publicly and privately supported research studies conducted in the United States and around the world. Search of this database for the study related to artificial passive immunization strategies against influenza returned 20 trials, 3 referring to maternal passive transfer immunity (described in the chapter Maternal antibodies against influenza and maternal cellular transfer of immunity) and the remaining 17 experiments, at various phases of clinical trials or without clear indication of the clinical phase, are shown in Table 2.

\section{Completed trials}

The safety studies (Phase 1 of clinical trials) were completed with three mAbs (CR6261, CR8020 and TCN032). Later, the Phase 2 trial (effectiveness) was finished with CR8020, however trials including both, CR6261 and CR8020, were withdrawn prior to enrollment due to preliminary efficacy results from an influenza challenge trial.

Two other completed clinical trials were connected with treatments of severe pandemic influenza A (2009 pdm H1N1) infections with human polyclonal Ig preparations. In the first one, the outcome of 20 cured patients treated with orally administered oseltamivir (75 $\mathrm{mg}$ ) along with $500 \mathrm{~mL}$ of convalescent plasma containing neutralizing Abs to 2009 pdm H1N1 was compared with an appropriate group treated with oral oseltamivir alone. Mortality, viral load as well as the levels of IL-6, IL-10 and TNF- $\alpha$ were significantly lower in the group that received the double treatment (Hung et al., 2011). Later, the efficacy of the treatment with H-IVIG $(0.4 \mathrm{~g}$ / $\mathrm{kg}$ ) has been assessed by the same group (Hung et al., 2013). The treatment correlated with reduced mortality. An interesting discussion regarding further research on H-IVIG can be found in a recent publication (Joob \& Wiwanitkit, 2013).

\section{Ongoing studies}

All four current studies are carried out by the U.S. National Institute of Allergy and Infectious Diseases (NIAID). One is a pilot study to determine safety of an anti-influenza H-IVIG. The preliminary results of Phase 2 study on development of $\mathrm{Ab}$ treatment for Avian Flu (ID No. NCT00383071) are already submitted on-line. The remaining two studies deal with collection of anti-influenza A immune plasma.

\section{Studies still recruiting participants/not yet begun}

Three out of four, non-yet started anti-influenza passive immunization clinical studies are currently recruiting participants (ID No. NCT02037282, NCT01719874, NCT01052480). More subjects are envisaged to be involved in the next study on anti-influenza H-IVIG by NIAID in order to assess the pharmacokinetics of such treatment during longer observation period and with higher doses (ID No. NCT02037282).

After successful completion of Phase 1, Theraclone Sciences, Inc prepares Phase $2 \mathrm{a}$, a double-blinded, placebo-controlled study of TCN-032 with subjects challenged with H3N2 influenza A virus (ID No. NCT01719874). The aim of another Phase 2 study is to assess safety, efficacy and pharmacokinetics of an immune plasma preparation for influenza A treatment (ID No. NCT01052480). The authors plan to enroll 150 adults, children and pregnant women hospitalized with influenza A (H1N1, H3N2) at risk of a severe disease.

The mysterious VIS410 mAb (ID No. NCT02045472) developed by Visterra Inc. was submitted as a candidate to Phase 1 clinical trial. The study does not yet recruit participants, however, the company claims that it will start in 2014. Unfortunately, information about this $\mathrm{Ab}$ is limited; according to data provided by Visterra Inc. (http://www.visterrainc.com/pipeline/vis410.html, accessed on July 9th, 2014), it binds a unique conformational epitope on the stem region of $\mathrm{HA}$ that is resistant to virus mutation and conserved across all influenza subtypes. The VIS410 Ab prevents membrane fusion between the viral and host membranes.

Studies with unknown status

Two studies (ID No. NCT01299142 and NCT01055990) have unknown status that has not been changed for over two years.

\section{MATERNAL ANTIBODIES AGAINST INFLUENZA AND MATERNAL CELLULAR TRANSFER OF IMMUNITY}

Every organism which has been either infected or vaccinated with a sufficient dose of an antigen, reacts with a specific response inducing a long-lasting immune memory. During pregnancy and lactation in mammals and during hatching in birds, Abs from mother's circulatory system are transferred to the progeny. In mammals, IgG class antibodies are transferred by placental cells to the fetus, while $\operatorname{IgA}$ class antibodies are secreted into milk. In birds, IgY class antibodies are transferred into the egg yolk.

Experiments with animals clearly indicated that maternal vaccination is important for protection of the offspring against influenza. For example, significant maternal protection of young ferrets against influenza virus has been observed (Hwang et al., 2010; Jakeman et al., 1989). In young mice, suckling on vaccinated mouse was apparently more important than thevaccination status of the mother, but both approaches together gave the best results (Zhang et al., 2013). Such effects were observed with both, DNA immunization and live-attenuated vaccines. Another interesting observation was that the presence of maternal Abs interferes with active immunization of mice offspring (Chen et al., 2007). Therefore, it has been proposed by the authors that mothers and their offspring should not be immunized with the same vaccine against influenza. Similar results were obtained in the case of hen immunization against avian influenza (Maas et al., 2011).

Several clinical experiments demonstrated that vaccination against influenza during pregnancy is safe and effective and diminishes a number of episodes of respiratory illness with fever in infants and their hospitalization rate (Benowitz et al., 2010; Brydak \& Nitsch-Osuch, 2014; Eick et al., 2011; Zaman et al., 2008). In most completed human trials the detailed breast-feeding-related data were usually not available and therefore these data cannot be correlated with results on vaccine efficiency. Fortunately, this situation has now changed. Recently completed Phase 2 trial was comparing the postpartum immunization of breast-feeding women with two classical 
vaccines (ID No. NCT01181323). The first results are already submitted on ClinicalTrials.gov website (http:// clinicaltrials.gov) with data on breast milk ELISA IgA and IgG titer to be added. Clinical trials to which participants are recruited (ID No. NCT01496079, no phase and NCT01034254, Phase 3) add the assessments of influenza antibody titer in maternal colostrum and breast milk in women immunized in early or late pregnancy.

It has been known for a long time that not only Abs but also immune cells can be transferred via placenta and milk. Maternal leukocytes were discovered for the first time in the cord blood over 40 years ago (Desai \& Creger, 1963). Recent data indicating that transplacental transfer of cells from mother to child (known as maternal microchimerism) takes place in $42 \%$ of normal pregnancies (Eikmans et al., 2014; Jeanty et al., 2014), provide a new perspective concerning the significance of transfer of immune system cells via placenta. It can be a potentially additional source of immunity against influenza or other infectious diseases gained by unimmunized and not-yet-infected child. Also in milk, besides the secretory IgA antibodies and previously known factors preventing bacterial infection such as lysozyme or lactoferrin, presence of leukocytes and stem cells has been confirmed (Hassiotou et al., 2012). Moreover, human milk contains numerous proteins, many of them known to possess immune properties (Roncada et al., 2013). Therefore, although passive immunity definition excludes cell transfer, complete research on immunity acquired from mothers should also take this phenomenon into consideration. Apparently, passive immunization works mainly as maternal immunity transferred after vaccination or infection during or before pregnancy/breast feeding. Reasonable vaccine programs for pregnant women can benefit by lowering hospitalization rates and fatal cases in infants less than 6 month old to whom vaccination against influenza is not recommended.

\section{CONCLUSIONS}

Not always the preventive active immunization is sufficient to effectively protect against influenza virus infection. Highly immunogenic epitopes of surface-exposed antigens of influenza virus are under strong evolutionary pressure to escape Ab-mediated neutralization. Therefore, cross-reactive broadly neutralizing Abs are relatively rare because they are usually directed against epitopes with lower immunogenic potential. This phenomenon increases the probability of mismatch between vaccine strains, which are selected six month before influenza season, and dominant/most dangerous infection in the vaccinated population. Therefore, administration of $\mathrm{pu}-$ rified broadly-neutralizing antibodies is sometimes the only way to succeed in virus clearance, despite high cost and time-consuming production of such antibodies. For the purposes of passive immunization Abs can be applied topically, by systemic injection or as a component of multipurpose vaccines. A short lasting protection provided by artificial passive therapies makes their massive usage unreasonable in prevention of infectious diseases. The costs and logistics of such treatments set this technique as a second line of defense against influenza virus, after antiviral drugs, and limit it to the very special cases and groups of high risk patients. Still, antibodies with broad-neutralizing activity might save lives during influenza pandemics.
Most of research on passive immunization against influenza focus on monoclonal full-length antibodies. They have longer half-life and can induce CDC and ADCC response. In the authors' opinion they are the most promising candidates for the artificial passive treatment. Nevertheless, simple and quick purification of polyclonal antibodies from convalescent sera remains the most frequent way to save lives in cases of severe infections with influenza virus non-responding to standard antiviral treatment.

Further research is needed to confirm a possibility of virus repression by intracellulary expressed or internalized recombinant antibody fragments targeting internal viral proteins. The $\mathrm{HI}$ and $\mathrm{MN}$ tests are the main in vitro, and animal challenge is the main in vivo, way of confirming passive immunization efficacy. Unfortunately, many antibodies are screened only against a narrow range of strains and administration protocols which complicates (if not makes impossible) their comparison. 'Gold standard' techniques like hybridoma and phage display are the most frequently used for selection of specific mAbs, however new technological approaches like sorting of immortalized memory B-cells stained with a labeled target, have already resulted in isolation of the most promising mAbs. Multiplicity of Abs and the sources of genes encoding Abs as well as diversity of selection methods increase a chance to achieve success.

Naturally acquired passive immunity - both in a form of Abs transferred through the placenta or milk and by maternal cellular transfer, is also investigated with growing interests. Those mechanisms are very important for prevention of influenza infection in children under 6 months old for whom vaccination is not recommended, as well as for vaccination programs with high failure risk due to covering the vaccine antigen by maternal Abs.

Both artificial (with mAbs and pAbs) and natural passive immunizations are subjects of ongoing clinical trials. Their results might be the milestones for passive immunization approaches against influenza in the future.

Finally, it is necessary to mention that various antiinfluenza Abs can be useful in other applications, for example in immunodiagnostics.

\section{Acknowledgements of financial support}

This work was supported by EU Innovative Economy Program, Grant No. WND-POIG.01.01.02-00-007/08.

\section{REFERENCES}

Babickova J, Tothova L, Boor P, Celec P (2013) In vivo phage display - a discovery tool in molecular biomedicine. Biotechnol Adv 31: 1247-1259.

Balazs AB, Bloom JD, Hong CM, Rao DS, Baltimore D (2013) Broad protection against influenza infection by vectored immunoprophylaxis in mice. Nature Biotechnoly 31: 647-652.

Beerli RR, Bauer M, Schmitz N, Buser RB, Gwerder M, Muntwiler S, Renner WA, Saudan P, Bachmann MF (2009) Prophylactic and therapeutic activity of fully human monoclonal antibodies directed against influenza A M2 protein. Virology J 6: 224.

Benjamin E, Wang W, McAuliffe JM, Palmer-Hill FJ, Kallewaard NL, Chen Z, Suzich JA, Blair WS, Jin H, Zhu Q (2014) A broadly neutralizing human monoclonal antibody directed against a novel conserved epitope on the influenza virus $\mathrm{H} 3$ hemagglutinin globular head. J Virology 88: 6743-6750.

Benowitz I, Esposito DB, Gracey KD, Shapiro ED, Vazquez M (2010) Influenza vaccine given to pregnant women reduces hospitalization due to influenza in their infants. Clinical Infectious Diseases: an Official Publication of the Infectious Diseases Society of America 51: 1355-1361.

Bouvier NM, Lowen AC (2010) Animal Models for Influenza Virus Pathogenesis and Transmission. Viruses 2: 1530-1563.

Brandenburg B, Koudstaal W, Goudsmit J, Klaren V, Tang C, Bujny MV, Korse HJ, Kwaks T, Otterstrom JJ, Juraszek J, van Oijen AM, 
Vogels R, Friesen RH (2013) Mechanisms of hemagglutinin targeted influenza virus neutralization. PloS one 8: e80034.

Brekke OH, Loset GA (2003) New technologies in therapeutic antibody development. Curr Opin Pharmacol 3: 544-550.

Brydak LB, Nitsch-Osuch A (2014) Vaccination against influenza in pregnant women Acta Biochim Polon 61: 589-591.

Bugli F, Cacaci M, Martini C, Torelli R, Posteraro B, Sanguinetti M, Paroni Sterbini F (2013) Human monoclonal antibody-based therapy in the treatment of invasive candidiasis. Clin Develop Immunol 2013: 403121.

Chen J, Zhang F, Fang F, Chang H, Chen Z (2007) Vaccination with hemagglutinin or neuraminidase DNA protects $\mathrm{BALB} / \mathrm{c}$ mice against influenza virus infection in presence of maternal antibody. BMC Infectious Dis 7: 118.

Clementi N, Criscuolo E, Castelli M, Clementi M (2012) Broad-range neutralizing anti-influenza A human monoclonal antibodies: new perspectives in therapy and prophylaxis. The New Microbiol 35: 399406.

Clementi N, De Marco D, Mancini N, Solforosi L, Moreno GJ, Gubareva LV, Mishin V, Di Pietro A, Vicenzi E, Siccardi AG, Clementi M, Burioni R (2011) A human monoclonal antibody with neutralizing activity against highly divergent influenza subtypes. PloS ONE 6: e28001.

Corti D, Voss J, Gamblin SJ, Codoni G, Macagno A, Jarrossay D, Vachieri SG, Pinna D, Minola A, Vanzetta F, Silacci C, FernandezRodriguez BM, Agatic G, Bianchi S, Giacchetto-Sasselli I, Calder L, Sallusto F, Collins P, Haire LF, Temperton N, Langedijk JP, Skehel JJ, Lanzavecchia A (2011) A neutralizing antibody selected from plasma cells that binds to group 1 and group 2 influenza A hemagglutinins. Science 333: 850-856.

De Marco D, Clementi N, Mancini N, Solforosi L, Moreno GJ, Sun $\mathrm{X}$, Tumpey TM, Gubareva LV, Mishin V, Clementi M, Burioni R (2012) A non-VH1-69 heterosubtypic neutralizing human monoclonal antibody protects mice against $\mathrm{H} 1 \mathrm{~N} 1$ and $\mathrm{H} 5 \mathrm{~N} 1$ viruses. PloS ONE 7: e34415.

Defang GN, Martin NJ, Burgess TH, Millar EV, Pecenka LA, Danko JR, Arnold JC, Kochel TJ, Luke TC (2012) Comparative analysis of hemagglutination inhibition titers generated using temporally matched serum and plasma samples. PloS ONE 7: e48229.

Desai RG, Creger WP (1963) Maternofetal passage of leukocytes and platelets in man. Blood 21: 665-673.

DiLillo DJ, Tan GS, Palese P, Ravetch JV (2014) Broadly neutralizing hemagglutinin stalk-specific antibodies require FcgammaR interactions for protection against influenza virus in vivo. Nat Med 20: $143-151$.

Doyle TM, Hashem AM, Li C, Van Domselaar G, Larocque L, Wang J, Smith D, Cyr T, Farnsworth A, He R, Hurt AC, Brown EG, Li $\mathrm{X}$ (2013) Universal anti-neuraminidase antibody inhibiting all influenza A subtypes. Antiviral Res 100: 567-574.

Dreyfus C, Laursen NS, Kwaks T, Zuijdgeest D, Khayat R, Ekiert DC, Lee JH, Metlagel Z, Bujny MV, Jongeneelen M, van der Vlugt R, Lamrani M, Korse HJ, Geelen E, Sahin O, Sieuwerts M, Brakenhoff JP, Vogels R, Li OT, Poon LL, Peiris M, Koudstaal W, Ward AB, Wilson IA, Goudsmit J, Friesen RH (2012) Highly conserved protective epitopes on influenza B viruses. Science 337: 1343-1348.

Du A, Daidoji T, Koma T, Ibrahim MS, Nakamura S, de Silva UC, Ueda M, Yang CS, Yasunaga T, Ikuta K, Nakaya T (2009) Detection of circulating Asian H5N1 viruses by a newly established monoclonal antibody. Biochem Biophys Res Commun 378: 197-202.

Edwards MJ, Dimmock NJ (2000) Two influenza A virus-specific Fabs neutralize by inhibiting virus attachment to target cells, while neutralization by their IgGs is complex and occurs simultaneously through fusion inhibition and attachment inhibition. Virology 278: 423-435.

Eick AA, Uyeki TM, Klimov A, Hall H, Reid R, Santosham M, O'Brien KL (2011) Maternal influenza vaccination and effect on influenza virus infection in young infants. Arch Pediatrics Adolescent Med 165: 104-111.

Eikmans M, van Halteren AG, van Besien K, van Rood JJ, Drabbels JJ, Claas FH (2014) Naturally acquired microchimerism: Implications for transplantation outcome and novel methodologies for detection. Chimerism 5 (Epub ahead of print).

Ekiert DC, Friesen RH, Bhabha G, Kwaks T, Jongeneelen M, Yu W, Ophorst C, Cox F, Korse HJ, Brandenburg B, Vogels R, Brakenhoff JP, Kompier R, Koldijk MH, Cornelissen LA, Poon LL, Peiris M, Koudstaal W, Wilson IA, Goudsmit J (2011) A highly conserved neutralizing epitope on group 2 influenza A viruses. Science 333: 843-850.

Ekiert DC, Kashyap AK, Steel J, Rubrum A, Bhabha G, Khayat R, Lee JH, Dillon MA, O’Neil RE, Faynboym AM, Horowitz M, Horowitz L, Ward AB, Palese P, Webby R, Lerner RA, Bhatt RR, Wilson IA (2012) Cross-neutralization of influenza A viruses mediated by a single antibody loop. Nature 489: 526-532.

Fang Y, Banner D, Kelvin AA, Huang SS, Paige CJ, Corfe SA, Kane KP, Bleackley RC, Rowe T, Leon AJ, Kelvin DJ (2012) Seasonal H1N1 influenza virus infection induces cross-protective pandemic
H1N1 virus immunity through a CD8-independent, B cell-dependent mechanism. Journal of virology 86: 2229-2238.

Fu TM, Freed DC, Horton MS, Fan J, Citron MP, Joyce JG, Garsky VM, Casimiro DR, Zhao Q, Shiver JW, Liang X (2009) Characterizations of four monoclonal antibodies against M2 protein ectodomain of influenza A virus. Virology 385: 218-226.

Fujimoto Y, Ozaki K, Maeda M, Nishijima K, Takakuwa H, Otsuki K, Kida H, Ono E (2013) Resistance to influenza A virus infection in transformed cell lines expressing an anti-PB2 monoclonal antibody. Veterinary J 198: 487-493.

Gamblin SJ, Skehel JJ (2010) Influenza hemagglutinin and neuraminidase membrane glycoproteins. J Biol Chem 285: 28403-28409.

Grandea AG, 3rd, Olsen OA, Cox TC, Renshaw M, Hammond PW, Chan-Hui PY, Mitcham JL, Cieplak W, Stewart SM, Grantham ML, Pekosz A, Kiso M, Shinya K, Hatta M, Kawaoka Y, Moyle M (2010) Human antibodies reveal a protective epitope that is highly conserved among human and nonhuman influenza A viruses. Proc Natl Acad Sci US A 107: 12658-12663.

Hairul Bahara NH, Tye GJ, Choong YS, Ong EB, Ismail A, Lim TS (2013) Phage display antibodies for diagnostic applications. Biologicals: Journal of the International Association of Biological Standardization 41: 209-216.

Hassiotou F, Beltran A, Chetwynd E, Stuebe AM, Twigger AJ, Metzger P, Trengove N, Lai CT, Filgueira L, Blancafort P, Hartmann PE (2012) Breastmilk is a novel source of stem cells with multilineage differentiation potential. Stem Cells 30: 2164-2174.

Heng BC, Cao T (2005) Making cell-permeable antibodies (Transbody) through fusion of protein transduction domains (PTD) with single chain variable fragment $(\mathrm{scFv})$ antibodies: potential advantages over antibodies expressed within the intracellular environment (Intrabody). Medical Hypotheses 64: 1105-1108.

Herbreteau CH, Jacquot F, Rith S, Vacher L, Nguyen L, Carbonnelle C, Lotteau V, Jolivet M, Raoul H, Buchy P, Saluzzo JF (2014) Specific polyclonal $\mathrm{F}(\mathrm{ab})$ neutralize a large panel of highly pathogenic avian influenza $\mathrm{A}$ viruses (H5N1) and control infection in mice. Immunotherapy 6: 699-708.

Howard MK, Sabarth N, Savidis-Dacho H, Portsmouth D, Kistner O, Kreil TR, Ehrlich HJ, Barrett PN (2011) H5N1 whole-virus vaccine induces neutralizing antibodies in humans which are protective in a mouse passive transfer model. PloS one 6: e23791.

Hu H, Voss J, Zhang G, Buchy P, Zuo T, Wang L, Wang F, Zhou F, Wang G, Tsai C, Calder L, Gamblin SJ, Zhang L, Deubel V, Zhou B, Skehel JJ, Zhou P (2012) A human antibody recognizing a conserved epitope of $\mathrm{H} 5$ hemagglutinin broadly neutralizes highly pathogenic avian influenza H5N1 viruses. J Virol 86: 2978-2989.

Huang L, Su X, Federoff HJ (2013) Single-chain fragment variable passive immunotherapies for neurodegenerative diseases. Int J Mol Sci 14: 19109-19127.

Hui DS, Lee N, Chan PK (2013) Adjunctive therapies and immunomodulatory agents in the management of severe influenza. Antiviral Res 98: 410-416.

Hung IF, To KK, Lee CK, Lee KL, Chan K, Yan WW, Liu R, Watt CL, Chan WM, Lai KY, Koo CK, Buckley T, Chow FL, Wong KK, Chan HS, Ching CK, Tang BS, Lau CC, Li IW, Liu SH, Chan KH, Lin CK, Yuen KY (2011) Convalescent plasma treatment reduced mortality in patients with severe pandemic influenza A (H1N1) 2009 virus infection. Clinical infectious diseases: an Official Publication of the Infectious Diseases Society of America 52: 447-456.

Hung IF, To KK, Lee CK, Lee KL, Yan WW, Chan K, Chan WM, Ngai CW, Law KI, Chow FL, Liu R, Lai KY, Lau CC, Liu SH, Chan KH, Lin CK, Yuen KY (2013) Hyperimmune IV immunoglobulin treatment: a multicenter double-blind randomized controlled trial for patients with severe 2009 influenza A(H1N1) infection. Chest 144: 464-473.

Hwang SD, Shin JS, Ku KB, Kim HS, Cho SW, Seo SH (2010) Protection of pregnant mice, fetuses and neonates from lethality of H5N1 influenza viruses by maternal vaccination. V accine 28: 2957-2964.

Iwatsuki-Horimoto K, Horimoto T, Noda T, Kiso M, Maeda J, Watanabe S, Muramoto Y, Fujii K, Kawaoka Y (2006) The cytoplasmic tail of the influenza A virus M2 protein plays a role in viral assembly. J Virol 80: 5233-5240.

Jakeman KJ, Smith H, Sweet C (1989) Mechanism of immunity to influenza: maternal and passive neonatal protection following immunization of adult ferrets with a live vaccinia-influenza virus haemagglutinin recombinant but not with recombinants containing other influenza virus proteins. J General Virol 70: 1523-1531.

Jeanty C, Derderian SC, Mackenzie TC (2014) Maternal-fetal cellular trafficking: clinical implications and consequences. Curr Opin Pediatrics 26: 377-382.

Joob B, Wiwanitkit V (2013) Hyperimmune IV immunoglobulin treatment of 2009 influenza A(H1N1). Chest 144: 712

Kaku Y, Noguchi A, Okutani A, Inoue S, Tanabayashi K, Yamamoto Y, Hotta A, Suzuki M, Sugiura N, Yamada A (2012) Altered specificity of single-chain antibody fragments bound to pandemic H1N12009 influenza virus after conversion of the phage-bound to the soluble form. BMC Res Notes 5: 483. 
Kashyap AK, Steel J, Oner AF, Dillon MA, Swale RE, Wall KM, Perry KJ, Faynboym A, Ilhan M, Horowitz M, Horowitz L, Palese P, Bhatt RR, Lerner RA (2008) Combinatorial antibody libraries from survivors of the Turkish H5N1 avian influenza outbreak reveal virus neutralization strategies. Proc Natl Acad Sci U S A 105: 5986-5991.

Keller MA, Stiehm ER (2000) Passive immunity in prevention and treatment of infectious diseases. Clin Microbiol Rev 13: 602-614.

Khurana S, Suguitan AL, Jr., Rivera Y, Simmons CP, Lanzavecchia A, Sallusto F, Manischewitz J, King LR, Subbarao K, Golding H (2009) Antigenic fingerprinting of $\mathrm{H} 5 \mathrm{N1}$ avian influenza using convalescent sera and monoclonal antibodies reveals potential vaccine and diagnostic targets. PLoS Medicine 6: e1000049.

Krause JC, Tsibane T, Tumpey TM, Huffman CJ, Basler CF, Crowe JE, Jr. (2011) A broadly neutralizing human monoclonal antibody that recognizes a conserved, novel epitope on the globular head of the influenza H1N1 virus hemagglutinin. J Virol 85: 10905-10908.

Krause JC, Tumpey TM, Huffman CJ, McGraw PA, Pearce MB, Tsibane T, Hai R, Basler CF, Crowe JE, Jr. (2010) Naturally occurring human monoclonal antibodies neutralize both 1918 and 2009 pandemic influenza A (H1N1) viruses. J Virol 84: 3127-3130.

Kubota-Koketsu R, Yunoki M, Okuno Y, Ikuta K (2012) Significant neutralizing activities against $\mathrm{H} 2 \mathrm{~N} 2$ influenza A viruses in human intravenous immunoglobulin lots manufactured from 1993 to 2010 . Biologics: Targets \& Therapy 6: 245-247.

Laursen NS, Wilson IA (2013) Broadly neutralizing antibodies against influenza viruses. Antiviral Rese 98: 476-483.

Lerner EA (1981) How to make a hybridoma. Yale J Biol Med 54: 387402.

Lim AP, Wong SK, Chan AH, Chan CE, Ooi EE, Hanson BJ (2008) Epitope characterization of the protective monoclonal antibody VN04-2 shows broadly neutralizing activity against highly pathogenic H5N1. Virology J 5: 80.

Liu W, Zou P, Chen YH (2004) Monoclonal antibodies recognizing EVETPIRN epitope of influenza A virus M2 protein could protect mice from lethal influenza A virus challenge. Immunol Lett 93: $131-136$.

Luke TC, Kilbane EM, Jackson JL, Hoffman SL (2006) Meta-analysis: convalescent blood products for Spanish influenza pneumonia: a future H5N1 treatment? Ann Int Medi 145: 599-609.

Maas R, Rosema S, van Zoelen D, Venema S (2011) Maternal immunity against avian influenza $\mathrm{H} 5 \mathrm{~N} 1$ in chickens: limited protection and interference with vaccine efficacy. Avian Pathology: Journal W.V.P.A 40: 87-92.

Mancini N, Solforosi L, Clementi N, De Marco D, Clementi M, Burioni R (2011) A potential role for monoclonal antibodies in prophylactic and therapeutic treatment of influenza. Antiviral Res 92: 15-26.

Mozdzanowska K, Maiese K, Furchner M, Gerhard W (1999) Treatment of influenza virus-infected SCID mice with nonneutralizing antibodies specific for the transmembrane proteins matrix 2 and neuraminidase reduces the pulmonary virus titer but fails to clear the infection. Virology 254: 138-146.

Mukhtar MM, Li S, Li W, Wan T, Mu Y, Wei W, Kang L, Rasool ST, Xiao Y, Zhu Y, Wu J (2009) Single-chain intracellular antibodies inhibit influenza virus replication by disrupting interaction of proteins involved in viral replication and transcription. Int J Biochem Cell Biol 41: $554-560$

Oh HL, Akerstrom S, Shen S, Bereczky S, Karlberg H, Klingstrom J, Lal SK, Mirazimi A, Tan YJ (2010) An antibody against a novel and conserved epitope in the hemagglutinin 1 subunit neutralizes numerous H5N1 influenza viruses. I Virol 84: 8275-8286.

Okada J, Ohshima N, Kubota-Koketsu R, Ota S, Takase W, Azuma M, Iba Y, Nakagawa N, Yoshikawa T, Nakajima Y, Ishikawa T, Asano Y, Okuno Y, Kurosawa Y (2010) Monoclonal antibodies in man that neutralized H3N2 influenza viruses were classified into three groups with distinct strain specificity: 1968-1973, 1977-1993 and 1997-2003. Virology 397: 322-330.

Pitaksajjakul P, Lekcharoensuk P, Upragarin N, Barbas CF, 3rd, Ibrahim MS, Ikuta K, Ramasoota P (2010) Fab MAbs specific to HA of influenza virus with H5N1 neutralizing activity selected from immunized chicken phage library. Biochem Biophys Res Communi 395: 496-501.

Poungpair O, Pootong A, Maneewatch S, Srimanote P, Tongtawe P, Songserm T, Tapchaisri P, Chaicumpa W (2010) A human single chain transbody specific to matrix protein (M1) interferes with the replication of influenza A virus. Bioconjugate Chem 21: 1134-1141.

Prabakaran M, Prabhu N, He F, Hongliang Q, Ho HT, Qiang J, Meng T, Goutama M, Kwang J (2009) Combination therapy using chimeric monoclonal antibodies protects mice from lethal H5N1 infection and prevents formation of escape mutants. PloS ONE 4: e5672.

Prabhu N, Prabakaran M, Ho HT, Velumani S, Qiang J, Goutama M, Kwang J (2009) Monoclonal antibodies against the fusion peptide of hemagglutinin protect mice from lethal influenza A virus H5N1 infection. J Virol 83: 2553-2562.

Rinaldi C, Penhale WJ, Stumbles PA, Tay G, Berry CM (2014) Modulation of innate immune responses by influenza-specific ovine polyclonal antibodies used for prophylaxis. PloS ONE 9: e89674.
Roncada P, Stipetic LH, Bonizzi L, Burchmore RJ, Kennedy MW (2013) Proteomics as a tool to explore human milk in health and disease. J Proteomics 88: 47-57.

Schirrmann T, Meyer T, Schutte M, Frenzel A, Hust M (2011) Phage display for the generation of antibodies for proteome research, diagnostics and therapy. Molecules 16: 412-426.

Shahzad MI, Naeem K, Mukhtar M, Khanum A (2008) Passive immunization against highly pathogenic Avian Influenza Virus (AIV) strain H7N3 with antiserum generated from viral polypeptides protect poultry birds from lethal viral infection. Virol J 5: 144.

Shoji Y, Chichester JA, Palmer GA, Farrance CE, Stevens R, Stewart M, Goldschmidt L, Deyde V, Gubareva L, Klimov A, Mett V, Yusibov V (2011) An influenza N1 neuraminidase-specific monoclonal antibody with broad neuraminidase inhibition activity against H5N1 HPAI viruses. Human Vaccines 7 (Suppl): 199-204.

Simmons CP, Bernasconi NL, Suguitan AL, Mills K, Ward JM, Chau NV, Hien TT, Sallusto F, Ha do Q, Farrar J, de Jong MD, Lanzavecchia A, Subbarao K (2007) Prophylactic and therapeutic efficacy of human monoclonal antibodies against H5N1 influenza. PLoS Medicine 4: e178.

Sui J, Hwang WC, Perez S, Wei G, Aird D, Chen LM, Santelli E, Stec B, Cadwell G, Ali M, Wan H, Murakami A, Yammanuru A, Han T, Cox NJ, Bankston LA, Donis RO, Liddington RC, Marasco WA (2009) Structural and functional bases for broad-spectrum neutralization of avian and human influenza A viruses. Nat Struct Mol Biol 16: $265-273$.

Sui J, Li W, Murakami A, Tamin A, Matthews LJ, Wong SK, Moore MJ, Tallarico AS, Olurinde M, Choe H, Anderson LJ, Bellini WJ, Farzan M, Marasco WA (2004) Potent neutralization of severe acute respiratory syndrome (SARS) coronavirus by a human mAb to $\mathrm{S} 1$ protein that blocks receptor association. Proc Natl Acad Sci US A 101: 2536-2541.

Sun L, Lu X, Li C, Wang M, Liu Q, Li Z, Hu X, Li J, Liu F, Li Q, Belser JA, Hancock K, Shu Y, Katz JM, Liang M, Li D (2009) Generation, characterization and epitope mapping of two neutralizing and protective human recombinant antibodies against influenza A H5N1 viruses. PloS ONE 4: e5476.

Thathaisong U, Maneewatch S, Kulkeaw K, Thueng-In K, Poungpair O, Srimanote P, Songserm T, Tongtawe P, Tapchaisri P, Chaicumpa W (2008) Human monoclonal single chain antibodies ( $\mathrm{HuScFv}$ ) that bind to the polymerase proteins of influenza A virus. Asian Pacific Journal of Allergy and Immunology/Launched by the Allergy and Immunology Society of Thailand 26: 23-35.

Thomas PG, Keating R, Hulse-Post DJ, Doherty PC (2006) Cell-mediated protection in influenza infection. Emerging Infectious Dis 12: 48-54.

Throsby M, van den Brink E, Jongeneelen M, Poon LL, Alard P, Cornelissen L, Bakker A, Cox F, van Deventer E, Guan Y, Cinatl J, ter Meulen J, Lasters I, Carsetti R, Peiris M, de Kruif J, Goudsmit J (2008) Heterosubtypic neutralizing monoclonal antibodies crossprotective against $\mathrm{H} 5 \mathrm{~N} 1$ and $\mathrm{H} 1 \mathrm{~N} 1$ recovered from human IgM+ memory B cells. PloS ONE 3: e3942.

Tillib SV, Ivanova TI, Vasilev LA, Rutovskaya MV, Saakyan SA, Gribova IY, Tutykhina IL, Sedova ES, Lysenko AA, Shmarov MM, Logunov DY, Naroditsky BS, Gintsburg AL (2013) Formatted single-domain antibodies can protect mice against infection with influenza virus (H5N2). Antiviral Res 97: 245-254.

Tong S, Zhu X, Li Y, Shi M, Zhang J, Bourgeois M, Yang H, Chen X, Recuenco S, Gomez J, Chen LM, Johnson A, Tao Y, Dreyfus C, Yu W, McBride R, Carney PJ, Gilbert AT, Chang J, Guo Z, Davis CT, Paulson JC, Stevens J, Rupprecht CE, Holmes EC, Wilson IA, Donis RO (2013) New world bats harbor diverse influenza A viruses. PLoS Pathogens 9: e1003657.

Tutykhina IL, Sedova ES, Gribova IY, Ivanova TI, Vasilev LA, Rutovskaya MV, Lysenko AA, Shmarov MM, Logunov DY, Naroditsky BS, Tillib SV, Gintsburg AL (2013) Passive immunization with a recombinant adenovirus expressing an HA (H5)-specific singledomain antibody protects mice from lethal influenza infection. Antiviral Res 97: 318-328.

Velkov T, Ong C, Baker MA, Kim H, Li J, Nation RL, Huang JX, Cooper MA, Rockman S (2013) The antigenic architecture of the hemagglutinin of influenza H5N1 viruses. Mol Immunol 56: 705-719.

Virdi V, Depicker A (2013) Role of plant expression systems in antibody production for passive immunization. Int J Develop Biol 57: 587-593.

Wallach MG, Webby RJ, Islam F, Walkden-Brown S, Emmoth E, Feinstein R, Gronvik KO (2011) Cross-protection of chicken immunoglobulin $\mathrm{Y}$ antibodies against $\mathrm{H} 5 \mathrm{~N} 1$ and $\mathrm{H} 1 \mathrm{~N} 1$ viruses passively administered in mice. Clin V accine Immunol: CVI 18: 1083-1090.

Wan H, Gao J, Xu K, Chen H, Couzens LK, Rivers KH, Easterbrook JD, Yang K, Zhong L, Rajabi M, Ye J, Sultana I, Wan XF, Liu X, Perez DR, Taubenberger JK, Eichelberger MC (2013) Molecular basis for broad neuraminidase immunity: conserved epitopes in seasonal and pandemic $\mathrm{H} 1 \mathrm{~N} 1$ as well as $\mathrm{H} 5 \mathrm{~N} 1$ influenza viruses. $J$ Virol 87: 9290-9300. 
Wang R, Song A, Levin J, Dennis D, Zhang NJ, Yoshida H, Koriazova L, Madura L, Shapiro L, Matsumoto A, Yoshida H, Mikayama T, Kubo RT, Sarawar S, Cheroutre H, Kato S (2008) Therapeutic potential of a fully human monoclonal antibody against influenza A virus M2 protein. Antiviral Res 80: 168-177.

Whaley KJ, Zeitlin L (2013) Antibody-based concepts for multipurpose prevention technologies. Antiviral Res 100 (Suppl): S48-S53.

Whittle JR, Zhang R, Khurana S, King LR, Manischewitz J, Golding H, Dormitzer PR, Haynes BF, Walter EB, Moody MA, Kepler TB, Liao HX, Harrison SC (2011) Broadly neutralizing human antibody that recognizes the receptor-binding pocket of influenza virus hemagglutinin. Proc Natl Acad Sci U S A 108: 14216-14221.

WHO (2013) Laboratory Procedures. Serological detection of avian influenza $\mathrm{A}(\mathrm{H} 7 \mathrm{~N} 9)$ infections by microneutralization assay. available on line: http://www.who.int/influenza/gisrs_laboratory/cnic_serological_diagnosis_microneutralization_a_h7n9.pdf

Wrammert J, Koutsonanos D, Li GM, Ėupuganti S, Sui J, Morrissey M, McCausland M, Skountzou I, Hornig M, Lipkin WI, Mehta A, Razavi B, Del Rio C, Zheng NY, Lee JH, Huang M, Ali Z, Kaur K, Andrews S, Amara RR, Wang Y, Das SR, O'Donnell CD, Yewdell JW, Subbarao K, Marasco WA, Mulligan MJ, Compans R, Ahmed R, Wilson PC (2011) Broadly cross-reactive antibodies dominate the human B cell response against 2009 pandemic H1N1 influenza virus infection. J Exp Med 208: 181-193.

Wu R, Li X, Leung HC, Cao Z, Qiu Z, Zhou Y, Zheng BJ, He Y (2014) A novel neutralizing antibody against diverse clades of H5N1 influenza virus and its mutants capable of airborne transmission. Antiviral Res 106: 13-23.

Xu Y, Li X, Jin L, Zhen Y, Lu Y, Li S, You J, Wang L (2011) Application of chicken egg yolk immunoglobulins in the control of terrestrial and aquatic animal diseases: a review. Biotechnol Adv 29: 860-868.

Yamazaki T, Nagashima M, Ninomiya D, Arai Y, Teshima Y, Fujimoto A, Ainai A, Hasegawa H, Chiba J (2011) Passive immune-prophylaxis against influenza virus infection by the expression of neutral- izing anti-hemagglutinin monoclonal antibodies from plasmids. Jap J Infectious Dis 64: 40-49.

Yang YE, Wen J, Zhao S, Zhang K, Zhou Y (2014) Prophylaxis and therapy of pandemic H1N1 virus infection using egg yolk antibody. J Virol Methods 206C: 19-26.

Yewdell JW, Frank E, Gerhard W (1981) Expression of influenza A virus internal antigens on the surface of infected P815 cells. I Immunol 126: 1814-1819.

Yoshida R, Igarashi M, Ozaki H, Kishida N, Tomabechi D, Kida H, Ito K, Takada A (2009) Cross-protective potential of a novel monoclonal antibody directed against antigenic site B of the hemagglutinin of influenza A viruses. PLoS Pathogens 5: e1000350.

Young KH (1998) Yeast two-hybrid: so many interactions, (in) so little time. Biol Reproduction 58: 302-311.

Yu X, Tsibane T, McGraw PA, House FS, Keefer CJ, Hicar MD, Tumpey TM, Pappas C, Perrone LA, Martinez O, Stevens J, Wilson IA, Aguilar PV, Altschuler EL, Basler CF, Crowe JE, Jr. (2008) Neutralizing antibodies derived from the B cells of 1918 influenza pandemic survivors. Nature 455: 532-536.

Zaman K, Roy E, Arifeen SE, Rahman M, Raqib R, Wilson E, Omer SB, Shahid NS, Breiman RF, Steinhoff MC (2008) Effectiveness of maternal influenza immunization in mothers and infants. New England J Med 359: 1555-1564.

Zebedee SL, Lamb RA (1988) Influenza A virus M2 protein: monoclonal antibody restriction of virus growth and detection of M2 in virions. J Virol 62: 2762-2772.

Zhang F, Fang F, Chang H, Peng B, Wu J, Chen J, Wang H, Chen Z (2013) Comparison of protection against H5N1 influenza virus in mouse offspring provided by maternal vaccination with HA DNA and inactivated vaccine. Arch Virol 158: 1253-1265.

Zhou B, Zhong N, Guan Y (2007) Treatment with convalescent plasma for influenza A (H5N1) infection. New England J Medi 357: 1450-1451. 